Article

\title{
Farmers Try to Improve Their Irrigation Practices by Using Daily Irrigation Recommendations-The Vipava Valley Case, Slovenia
}

\author{
Rozalija Cvejić $^{1, *(D)}$, Majda Černič-Istenič ${ }^{1}$, Luka Honzak ${ }^{2}$ (D) Urša Pečan ${ }^{1}$, Špela Železnikar ${ }^{1}$ \\ and Marina Pintar ${ }^{1}$ \\ 1 Department of Agronomy, Biotechnical Faculty, University of Ljubljana, Jamnikarjeva 101, 1000 Ljubljana, \\ Slovenia; majda.cernic.istenic@bf.uni-lj.si (M.Č.-I.); ursa.pecan@bf.uni-lj.si (U.P.); \\ spela.zeleznikar@bf.uni-lj.si (Š.Ž.); marina.pintar@bf.uni-lj.si (M.P.) \\ 2 BO-MO Ltd., Bratovševa Ploščad 4, 1000 Ljubljana, Slovenia; luka@bo-mo.si \\ * Correspondence: rozalija.cvejic@bf.uni-lj.si
}

Received: 13 July 2020; Accepted: 18 August 2020; Published: 21 August 2020

check for updates

\begin{abstract}
Based on the latest climate change projections for the 21st century, high exposure to climate change is expected in Vipava Valley, Slovenia's sub-Mediterranean agricultural area. An irrigation-decision support system was developed and implemented on 35 farms in the period of 2016-2020 to increase agricultural climate-change resilience. Farmers have shifted from irrigation scheduling based on experience and assumptions to irrigation scheduling based on real-time soil-water monitoring to partially implement irrigation based on irrigation-decision support systems. Simulations show that if farmers continue to practice justified irrigation applications and gradually transition to replenishing soil water reservoir content to $85 \%$, they will achieve a $25 \%$ reduction in total irrigation-volume consumption, a $24 \%$ reduction in energy requirements and a $24 \%$ reduction in $\mathrm{CO}_{2}$ emissions. Future agricultural innovation policies should extend actions beyond the financial to those facilitating the establishment of multidisciplinary agricultural innovation teams with corresponding infrastructures to better enable the mutual exchange of knowledge, learning and development of a transparent institutional framework.
\end{abstract}

Keywords: irrigation-decision support system; irrigation scheduling; climate change

\section{Introduction}

The European Commission's Communication on the European Green Deal announced the development of a new, more ambitious EU climate-change strategy to enhance endeavors related to climate resilience, prevention and preparedness. Several regulatory and technical approaches have been undertaken to increase water and energy use efficiency and reduce $\mathrm{CO}_{2}$ emissions in terms of irrigated agriculture; for example, pressure networks have replaced outdated open distribution systems, and irrigation systems have been improved by utilizing more efficient water delivery equipment, such as drippers and sprinklers. Government regulators have responded by requiring abstraction permits, setting abstraction limits and establishing a minimum practice for irrigation water use efficiency; despite this, poor irrigation scheduling practice remains a major challenge because of scheduling technique complexity, the cost and inaccessibility of soil-water monitoring tools and lack of local climate data and soil-water parameters [1,2].

Research indicates that irrigation scheduling using soil-moisture sensors reduces water requirements while improving yield, irrigation efficiency and net yield [3,4]. Examples show that total irrigation volume can be reduced by up to $25-40 \%$ without affecting crop yield by reducing 
the current irrigation surplus when there is above-average or near-average seasonal precipitation [5]. Achieving high productivity using less irrigation and better matching irrigation volumes to crop water requirements are compatible goals [5]. It is possible to reduce energy costs while improving water use efficiency through comprehensive irrigation management; energy cost savings of nearly $15 \%$ are achievable without significant yield reduction [6]. Improved farm irrigation management enables a $40 \%$ reduction in $\mathrm{CO}_{2}$ emissions [7]; to do so comprehensive irrigation-decision support systems (IDSSs) tools are required to optimize water consumption and plant production based on regional climate conditions and farming systems [8-13].

Even so, IDSS implementation faces several challenges. A lack of consistency between environmental variability and irrigation system design, insufficient information on plant water demand and spatial variability within farms and low control of the water distribution network limits IDSSs' contribution to efficient water use and agricultural climate-change resilience [14]. The use of IDSSs by farmers is far below what is possible [15,16]. Some researchers [16] consider linear, technology-supported approaches to be the main reason for this. In contrast, co-innovation, including inter alia close cooperation among experts, farmers and other stakeholders, supposedly improves IDSS uptake.

The introduction of IDSS requires careful consideration of farmer motivation, need and expectation $[17,18]$. The adoption of technology to mitigate climate change depends on a number of psychological and socioeconomic preconditions [16,19-21], as well as cultural and symbolic capital factors $[18,22,23]$. It requires the involvement of farmers $[16,17,24,25]$, experts from different disciplines [16], as well as non-academic stakeholders [21,26-28] at all phases of the innovation process. The farmers' extension service, traditionally the main actor in this system, is now only one of the services tasked with this role additionally challenged by taking over this role due to lacking appropriate competencies [29-32].

IDSS implementation is most often a process beginning with an evaluation of farm practice, followed by the creation of an accurate irrigation plan that may include exact plant water requirements and installation of soil moisture sensors, smart water meters, programmers, electrovalves and weather stations. This process is usually followed by development of an application to provide farmers with irrigation advice for optimal irrigation planning [33]. However, farmers use a range of options to meet their specific need, some use fully functional irrigation controllers, others will gradually start using IDSSs-initially only an individual component-particularly the web-based graphic interface for farmer-controlled irrigation scheduling [4].

This article offers insight into improving farm irrigation scheduling and provides policy lessons to optimize water and energy consumption and reduce irrigated agriculture $\mathrm{CO}_{2}$ emissions. The research highlights IDSS adoption in sub-Mediterranean Vipava Valley, a region vulnerable to climate change. There are 2,518 agricultural holdings in Slovenia's Vipava Valley, amounting to 11,337 ha of agricultural land in use. The development of intensive agriculture in the area is threatened by natural disasters, which are becoming more frequent because of climate change: drought, flooding and strong winds caused damage worth more than $€ 15$ million damage between 2012 and 2014 [2]. The latest climate change projections for the 21st century indicate high exposure to climate change and further deterioration of existing agricultural conditions. Based on EUROCORDEX climate simulation [34], using the moderately optimistic RCP4.5 scenario, that assumes significant measures to reduce future greenhouse gas releases, an increase in average annual temperature $\left(+1.8^{\circ} \mathrm{C}\right)$, a decrease in summer precipitation $(-4 \%)$, and an increase in summer evapotranspiration $(+6 \%)$ are predicted [35]. Additionally, an increase of warm (maximum temperature exceeds $25^{\circ} \mathrm{C}$ ) and hot days (maximum temperature exceeds $30^{\circ} \mathrm{C}$ ), and an increase of number of days with precipitation above $20 \mathrm{~mm}$ are expected in the area by the end of the 21st century [36].

Our aim is to detect, analyze and present challenges and provide solutions to introducing the IDSS at the case study in Slovenia to be able to draw policy lessons from experience gained when involving farmers in setting up IDSS. The hypothesis was that farmers would gradually start using daily irrigation 
advice and increase water and energy consumption efficiency and reduce $\mathrm{CO}_{2}$ emissions. Different regulatory instruments, such as standards and recommendations, education, institutional support and information and economic instruments, including incentives, are discussed as standalone or combined instruments to provide alternative policy options for achieving better irrigation efficiency and greater agricultural resilience to climate change in the area. The experience gained from the introduction of different tools to improve irrigation planning on farms that is brought together in a discussion based on our findings and findings from the international scientific community support the development of the new EU strategy for adaptation to climate change.

\section{Materials and Methods}

\subsection{Case Study Area and the Existing Irrigation Practices}

The IDSS implementation process in the case study area was carried out over the period 2016-2020, with average monthly air temperatures in 2017,2018 and 2019 being 13.05, 13.9 and $13.4{ }^{\circ} \mathrm{C}$, respectively. The annual precipitation in the years 2017, 2018 and 2019 was 1450.5, 1079 and $1324.7 \mathrm{~mm}$, respectively. The monthly climatography is given in Figure 1. With regard to the long-term average (1981-2010) in the vegetative period, the average monthly temperature was above it in all three years and the monthly precipitation was below it for half of the vegetative period in 2017 and 2019 and during the whole of 2018 [37]. Spring frostbite significantly influenced yields in all three years.

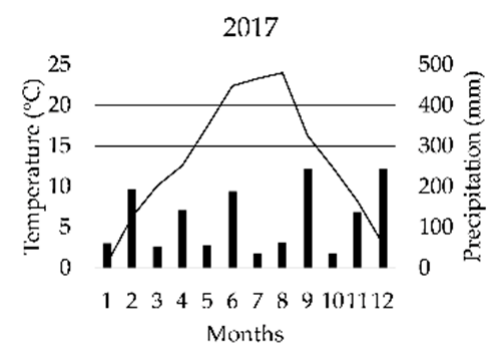

(a)

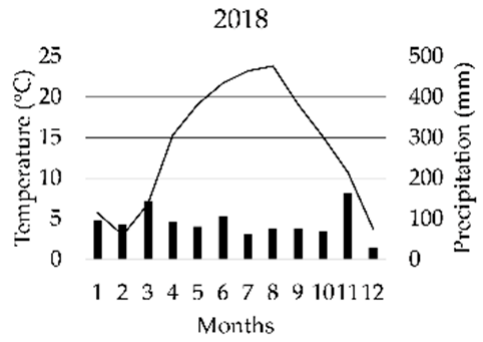

(b)

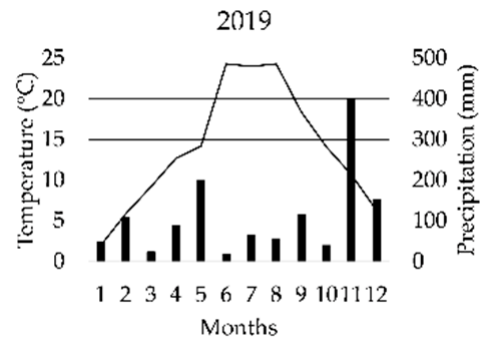

(c)

Figure 1. Average monthly air temperature $\left({ }^{\circ} \mathrm{C}\right)$ (line) and precipitation (mm) (bars) at Vipava Valley in: (a) 2017, (b) 2018 and (c) 2019.

Numerous measures have been applied to improve irrigation water availability during dry periods at the case study area (Figure 2) (large and small water reservoirs; micro and drip irrigation; heat-resistant plants, greenhouses and agrometeorological variable monitoring). Large-scale irrigation introduced in the 1970s, did not achieve its full potential due to a lack of maintenance, deterioration, the reduced scope of the measures and changes in their management [2]. The LIFE VIVaCCAdapt project was launched in 2016 to integrate the effect of all measure applied by introducing the IDSS. At that time, two existing IDSSs were used in Slovenia: The IDSS managed by Slovenian Institute of Hop Research and Brewing based on gravimetrical soil water content monitored with a one-day delay; and the IDSS run by the Slovenian Environment Agency based on modeled water balance using the irrigation-forecast model (IRRFIB) [38,39]. The IDSS applied in the LIFE VIVaCCAdapt project is based on the latter, but is upgraded to calculate the recommended time and amount of irrigation for 5 days, integrating soil-water retention properties, real-time measurement of soil water content, plant water requirements (phenological phase) and precipitation and evapotranspiration forecasting. 


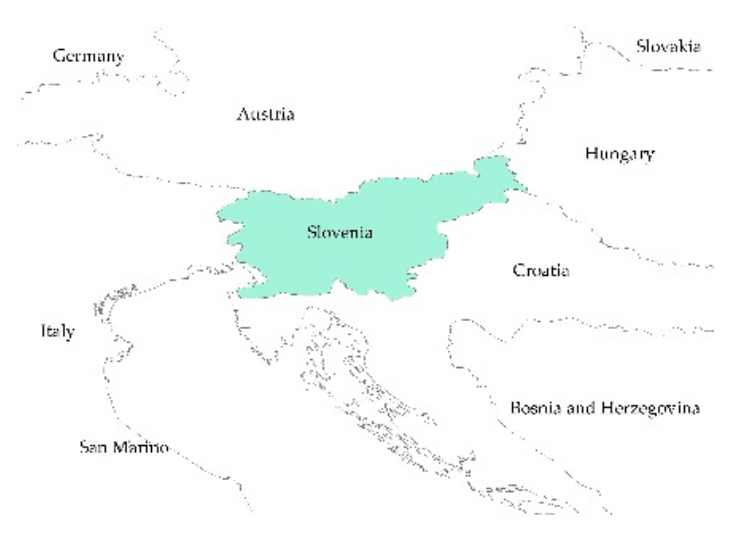

(a)

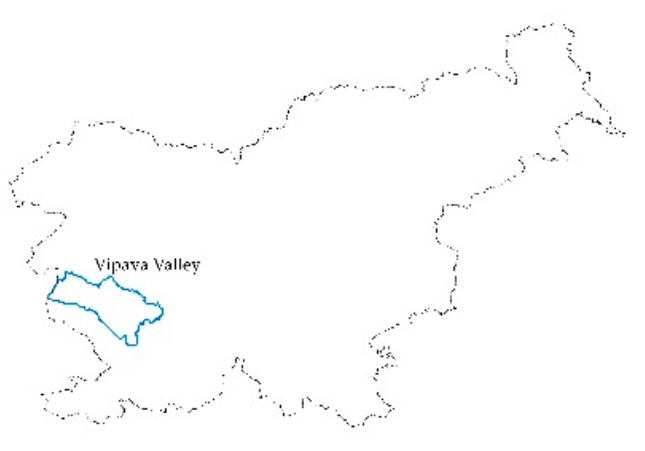

(b)

Figure 2. Case study area. (a) Country location; (b) Vipava Valley location.

A variety of methods (interviews, workshops, field inventories, phone consultations and individual work with farmers) were applied during the five-year process (Table 1). A public call for farmer IDSS participation was issued in October 2016, and 35 farms were interested, representing $1.4 \%$ of all agricultural holdings or 207.15 ha, that is, $1.8 \%$ of agricultural land in use in the area. The principles of the IDSS and its potential benefits for water, energy and $\mathrm{CO}_{2}$ consumption were explained to farmers at the first farmers' workshop in November 2016. Farmers were provided with an introduction to the main soil-water and plant parameters and different soil moisture measuring devices. Additionally, they could freely ask any question related to IDSS functioning and use, including lower water and energy consumption, higher yields and improved economic farm performance.

The farmers signed an agreement to participate in the IDSS development process, which means that 38.5 ha $(0.3 \%)$ of the agricultural land in use was included in the case study. The average size of the participating farms is 7.6 ha (slightly larger than the average Slovenian farm that is 6.9 ha). Participating holdings mainly specialize in permanent crops (74\%); others focus horticulture and field crops, (grazing) livestock, granivores, mixed crops-or a combination of these. Most of the participating farmers $(63 \%)$ were active in agriculture for more than 20 years. Majority of farmers $(71 \%)$ is open to introducing innovation practices. The most common irrigation technique used by the participating farms is drip irrigation, followed by high stable sprinklers, micro-irrigation and low-stable sprinklers. The variety of crops is included in the introduction to the IDSS, predominantly peaches, apricots and garlic (Table A1 in Appendix A).

Farmer irrigation practice was analyzed by means of field interviews in March 2017, whereby farmers were requested to share information about farm water availability, irrigation requirements in wet and dry years and to describe how they make their irrigation decisions. Farmers were requested to record their daily on-farm irrigation activities for 2017-2019 using irrigation diaries. The aim was to record each irrigation event, duration and amount of water applied during irrigation, to provide a more in-depth overview of existing irrigation practice at farms. 
Table 1. Overview of activities for the introduction and uptake of irrigation decision support tool at the case study area.

\begin{tabular}{|c|c|c|c|c|c|c|}
\hline Aim & Activity & 2016 & 2017 & 2018 & 2019 & 2020 \\
\hline \multirow{4}{*}{$\begin{array}{c}\text { IDSS UPTAKE BY } \\
\text { FARMERS }\end{array}$} & Participation agreement & $\mathrm{x}$ & & & & \\
\hline & Farmer's workshops & $\mathrm{x}$ & $\mathrm{x}$ & $\mathrm{x}$ & $\mathrm{x}$ & \\
\hline & Irrigation technology inventory & & & $\mathrm{x}$ & $x$ & \\
\hline & Phone consultations to farmers & & & & & $x$ \\
\hline \multirow{2}{*}{ IDSS EVALUATION } & First experience using IDSS & & & & $\mathrm{x}$ & \\
\hline & Continuous evaluation of irrigation practice & & & & & $\mathrm{x}$ \\
\hline \multicolumn{7}{|l|}{ IDSS SETUP } \\
\hline \multirow{2}{*}{ ON FARM } & Irrigation practice habits & & $\mathrm{x}$ & & & \\
\hline & Irrigation diaries & & $x$ & $x$ & $x$ & $x$ \\
\hline \multirow{3}{*}{ Plants and soil } & Soil texture, soil-water retention curves & & $x$ & & & $x$ \\
\hline & Plant development phases & & $x$ & & & \\
\hline & Installation & & $x$ & & & \\
\hline \multirow{5}{*}{ Soil moisture sensors } & Replacement of batteries & & & $\mathrm{x}$ & $\mathrm{x}$ & $\mathrm{x}$ \\
\hline & Replacement of damaged cables & & & $\mathrm{x}$ & $\mathrm{x}$ & $x$ \\
\hline & Replacement of inactive sensors & & & & & $x$ \\
\hline & Development of IDSS prototype & & $\mathrm{x}$ & & & \\
\hline & Development of IDSS & & & $\mathrm{x}$ & & \\
\hline \multirow[t]{5}{*}{ Software } & Bug fixing & & & & $\mathrm{x}$ & \\
\hline & Upgrades based on user feedback & & & & & $x$ \\
\hline & Inclusion of irrigation duration based on equipment inventory & & & & & $x$ \\
\hline & Agreement on right to use model IRRFIB 03.1 & & $x$ & & & \\
\hline & IDSS presented to the Central Action Group for Irrigation & & $\mathrm{x}$ & & & \\
\hline \multirow[t]{3}{*}{ Dissemination } & $\begin{array}{c}\text { IDSS implementation in other regions of Slovenian (European } \\
\text { Innovation Partnership projects) }\end{array}$ & & & $\mathrm{x}$ & $\mathrm{x}$ & \\
\hline & $\begin{array}{c}\text { Promotion of IDSS at national agricultural fairs, conferences, national } \\
\text { training of public irrigation advisers }\end{array}$ & & & $\mathrm{x}$ & $\mathrm{x}$ & \\
\hline & $\begin{array}{l}\text { Policy recommendations to financially support IDSS use by farmers } \\
\text { and to establish a public irrigation decision support service }\end{array}$ & & & $\mathrm{x}$ & $\mathrm{x}$ & \\
\hline
\end{tabular}




\subsection{Setting Up Irrigation-Decision Support System}

On-farm texture (Table A2 in Appendix A) and soil-water retention characteristics (field capacity and wilting point) (Table A3 in Appendix A) were analyzed in the spring of 2017. Soil-water content was measured using time domain reflectometry sensors, MVZ 100 (Eltratec Trade, Production and Services, Ltd.) that do not integrate temperature measurements. Soil-water content was measured at depths between $0.2 \mathrm{~m}$ and $0.3 \mathrm{~m}$ at $30 \mathrm{~min}$ intervals and transmitted twice per day through GSM loggers. The sensors have still been under development in the sense of being manufactory calibrated only for glass beads substrate, but not yet for various soil types. To ensure accuracy of sensors we performed a soil-specific calibration for each site/soil type. We determined MVZ 100 sensor volume influence [40], obtained undisturbed soil samples from each location and gravimetrically determined soil moisture in the laboratory [41-43]. The soils samples were taken in the vicinity $(0.5 \mathrm{~m}$ around $)$ of the soil moisture sensor installation location. Although we cannot expect exactly the same soil properties near the sensor, we simplified and assumed the soils are homogenous within a given range. The depth of the sampling site was recorded. The soil sample sites were locally marked with marking out stakes.

At least nine calibration points were obtained for each soil type, site-specific calibration functions for all sites were determined using regression analysis. Based on the calibration data for all sites, the accuracy of used sensors with manufactory calibration, expressed in root mean square error (RMSE), was between $3.8 \mathrm{vol} \%$ and $14.2 \mathrm{vol} \%$ (median $9.9 \mathrm{vol} \%$ ) and after the soil-specific calibration, it was greatly improved and ranged between $0.4 \mathrm{vol} \%$ and $2.9 \mathrm{vol} \%$ (median 1.5). Accuracy of the sensors after calibration as determined by the RMSE ranged between 0.004 and $0.029 \mathrm{~m}^{3} / \mathrm{m}^{3}$. Initially each participating farm was installed with one soil moisture sensor (at a depth of $0.2 \mathrm{~m}$ to $0.3 \mathrm{~m}$ ); in 2020 each farm was installed with a second soil moisture sensor (at the location of the first sensor, at a depth $0.4 \mathrm{~m}$ to $0.5 \mathrm{~m}$ ) to observe soil water content at lower depths.

The IDSS applied in this research is based on the IRRFIB water balance model [38,39]. The recommended time and irrigation amount is calculated for 5 days in advance, considering soil-water retention properties (soil-analysis data), real-time soil water content measurement (monitoring data), plant water requirements in given phenological phases [44] and weather forecast (precipitation and evapotranspiration) [37]. Water balance (WB) on day $i$ is calculated as follows:

$$
\text { WB (i) }[\mathrm{mm}]=\mathrm{WB}(\mathrm{I}-1)[\mathrm{mm}]+\text { Precipitation (i) }[\mathrm{mm}]-\text { ETc (i) }[\mathrm{mm}]+\mathrm{Vv}(\mathrm{N})[\mathrm{mm}]
$$

where ETc is potential crop evapotranspiration, $\mathrm{Vv}_{\mathrm{v}}(\mathrm{N})$ the surplus of water from previous days if there was higher rainfall than expected, that is WB above field capacity (FC) and N the number of days based on soil type [39]. Reference evapotranspiration is calculated using FAO Penman-Monteith method [45].

If WB is greater than FC, it is set as FC and the excess is stored in Vv; if WB is lower than WP, it is set as WP and if VB is less than CP (critical point) the ETc is halved. The effect of drought stress on the plant is described by reduced values of the plant coefficient [45] expressed as the product of the coefficient of the plant with the coefficient of stress (Ks). In simplification, the model assumes that from the point of defined stress evapotranspiration of the plant is halved [39]. Plant coefficient Kc and root depth for each day [44] are calculated in relation to the current phenophase onset date and the predicted onset of the next one with a linear scheme.

IDSS provided farmers with information on when to start irrigation (close to or at the critical point) and when to stop irrigation. For this purpose, we upgraded the IRRFIB model by developing additional functionalities, such as minimum irrigation amount and irrigation efficiency based on irrigation technology. Furthermore, two additional irrigation strategies were added: (i) replenishing soil water content to FC; and (ii) replenishing soil water reservoir (FC-WP) to $85 \%$. The first strategy was introduced to avoid water loss resulting from over irrigation. It was recognized from farmers practice beforehand that farmers irrigate rarely; but when they do, they usually overirrigate. The 
second strategy was introduced as an option to increase rainfall use efficiency (e.g., create storage for rainfall) as recommended in areas where frequent rainfall can help replenish soil water content [46] and where climate change simulations predict higher frequency of more intense rainfall events, such as it is the case at Vipava Valley [36]. In 2019 farmers were given daily recommendations based on the first strategy. Comparing their irrigation practice with influence of rainfall events on water balance and based on observing soil moisture content we consulted with farmers about implementing the second strategy (replenishing soil water reservoir to $85 \%$ ) in cases where farmers irrigate more often (1-3-day frequency). The second strategy was implemented at half of 2020 vegetation season. Users receive irrigation recommendations that consist (i) irrigation recommendation (evapotranspiration and precipitation forecasts), (ii) daily irrigation advice for five days and (iii) phenology information (onset of previous, current and phenophase) via email. The 'Web Interface' module of IDSS provides the same information as irrigation recommendation sent to user by email and additionally provides soil water content chart for the preceding 90 days.

\subsection{Evaluation of Irrigation-Decision Support System Implementation}

The baseline or justified irrigation requirements for farms were calculated using the IRRFIB model for IDSS evaluation. The exact irrigation equipment for farms, predefining maximum on-farm water and energy consumption, is based on telephone interviews made with the involved farmers in the spring of 2018 and field inventories in the winter of 2019. We calculated $\mathrm{CO}_{2}$ emissions generated by irrigation (see example of a calculation procedure for drip irrigation in Appendix B) in line with the rules on the methods for determining energy savings [47,48]. Data from the most representative meteorological station Bilje was used for daily reference evapotranspiration and precipitation [37]. We estimated initial soil moisture loss to be $0 \%$ at the beginning of the water balance simulation (the beginning of the growing season). We performed simulations for the period 2017-2019 for two irrigation strategies: (i) replenishing soil water content to FC; and (ii) replenishing soil water content to $85 \%$ capacity (FC-WP).

The project team discussed with the farmers their previous experience using IDSS at the workshop. Only one farmers experiencing the use of IDSS or soil moisture sensors, which is in line with IDSS development and general use among farmers in Slovenia in 2017. First experience using IDSS on farms was analyzed using an online questionnaire and discussed with the participating farmers at the third workshop in 2019. Farmers described how they use the IDSS, what information they most often use from the website, how often they used the IDSS in 2019, whether they encountered problems with its functioning and what suggestions they have for improving it. The strategy of recording farmer irrigation practice and IDSS use was adapted in 2020, when one-to-one telephone conversations were implemented, with irrigation action recorded every third week. This yielded more complete irrigation diaries and created a more constant overview of farmers' irrigation actions.

\section{Results}

In 2017, before IDSS implementation, most farmers' irrigation based on previous experience $(74 \%)$ and experience and daily weather forecasts $(23 \%)$, while only one used a soil moisture sensor. The majority had no water consumption records $(74 \%)$ and only $26 \%$ used water meters. Water consumption on-farm was rarely recorded. Most farmers (69\%) were able to report water use in dry years $\left(\mathrm{m}^{3} / \mathrm{ha}, \mathrm{m}^{3} /\right.$ year$)$, while $31 \%$ were unable to report annual water consumption. None of the farmers reported water use in wet years, indicating that irrigation is unnecessary in such years and that irrigation requirements vary considerably from year-to-year. Initial irrigation diaries proved too detailed for the farmers' level of knowledge and were simplified to include only records of irrigation events; even so, $91 \%$ of our farmers failed to regularly record their actions. It suggests that some farmers were not appropriately motivated to fully participate in the project (reasons given were a lack of time, lost questionnaires) while others were unable to irrigate due to force majeure (spring frost). 
Simulation highlights the difference between the two irrigation strategies: (i) replenishing soil water content to FC; and (ii) replenishing reservoirs (FC-WP) to $85 \%$ to allow a $25 \%$ average reduction in total irrigation-volume consumption. It is also possible to reduce energy requirements by $24 \%$ by improving water use efficiency; moreover, it has been evidenced that improved farm irrigation management can help reduce $\mathrm{CO}_{2}$ emissions by $24 \%$ (Figure 3), in line with the findings of [5-7]. For more detail see Appendix C, Tables A4-A12.

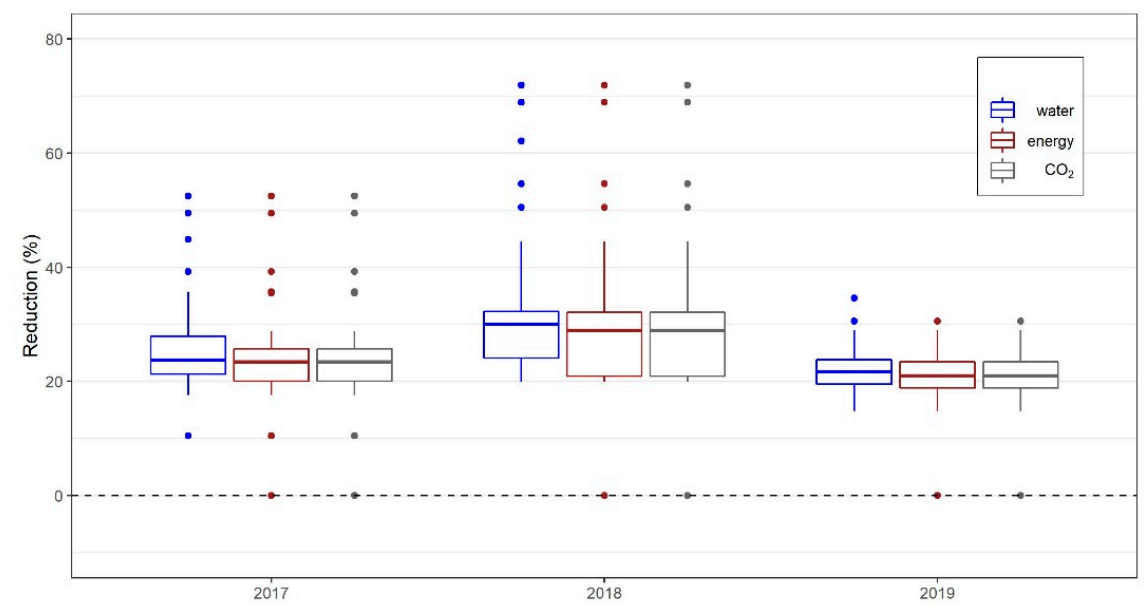

Figure 3. Simulated reduction of irrigation water and energy requirements and $\mathrm{CO}_{2}$ emissions by reducing the rate of soil reservoir replenishment (FC-WP) from 100 to $85 \%$.

In 2019, $66 \%$ of our farmers shared their first experience of IDSS on their farms. Forty-six farmers use the irrigation advice they receive by e-mail, $20 \%$ also use the IDSS website. 'Soil moisture' is the most commonly used tab on the IDSS website at $37 \%$, a combination of 'soil moisture' and 'net irrigation requirements' accounted for $11 \%$ and 'net irrigation requirements' accounting for $9 \%$, with only one farmer reporting use of all of the tabs. This indicates a significant change in the way farmers make irrigation decisions. Bearing in mind that those farmers initially only irrigated in terms of experience, they now report using a web platform that supports irrigation decisions. Discussion with farmers at the third workshop evidenced that using the web platform makes them feel better informed about plant water requirements and that their knowledge has increased significantly in this regard.

In $2019,40 \%$ of our farmers used irrigation recommendations more than five times per year, $9 \%$ used them at least three times, with $6 \%$ only using them once. Although $11 \%$ did not use irrigation recommendations, they reported that they regularly checked soil moisture measurements. Even so, the provided IDSS information only marginally affected farmer irrigation practice in terms of water consumption, in all probability due to insufficient farmer knowledge on how to convert soil water volume content into irrigation duration. This signifying the importance of establishing a detailed inventory of farm irrigation systems prior to IDSS implementation. However, low utilization of IDSS could also be related to the overly technical approach adopted, which emphasizes the technical functioning of the system and not farmer benefit, which better motivates them.

Manual phenological phase adjustment is crucial when formulating relevant irrigation advice. Farmers are responsible for IDSS phenophase updating. Merely 5 users changed phenological stages in 2019, which is why the irrigation advice for most farmers had larger error than if users had more frequently updated phenophases.

Farmers shared their opinion on how their user-experience could be improved by means of the questionnaire and during discussion at the third workshop. In some cases, farmers stated that soil-moisture sensors location could be optimized to better respond to irrigation (closer to drippers) or installed deeper to better capture main root depth. Individual farmers reported that they think that irrigation advice overestimates their on-field water requirements. Based on our analysis of on-farm irrigation practice before IDSS, farmers irrigated rarely, but when they did, they usually used too much 
water. We assume that when farmers were presented with their justified daily irrigation requirements, they automatically believed them to be excessive. Nevertheless, the mid-term evaluation of IDSS indicates that farmers are able to adapt and follow IDSS irrigation advice. The process indicates that change in farmer behavior will take several years and require consistent on-farm presence. Farmers have taken a first step towards using the IDSS, mainly to provide them with information on when to start irrigation (close to or at critical point) and when to stop irrigation (at FC or $85 \%$ of soil water reservoir). We expect that as the IDSS becomes more common, farmers will also start to use it to provide them with information on how much water to apply.

Figure 2 suggests that higher irrigation efficiency, achieved by changing farmer behavior by introducing the IDSS, will only contribute to better agricultural resilience to climate change after the initial period of IDSS implementation, in about five years. Farmers have in first three years made an enormous shift from irrigation decisions based on experience and assumptions to irrigation scheduling based on real-time soil-water monitoring, including the partial uptake of irrigation based on the IDSS. In doing so, they have improved irrigation scheduling accuracy and slowly begun to use more technologically advanced methods for irrigation planning. The simulation of justified water requirements shows that when farmers would use the IDSS more regularly, they would also significantly contribute to increased water and energy efficiency and $\mathrm{CO}_{2}$ emission reduction, thereby gradually increasing farms resilience to climate change in Vipava Valley (Figure 4).

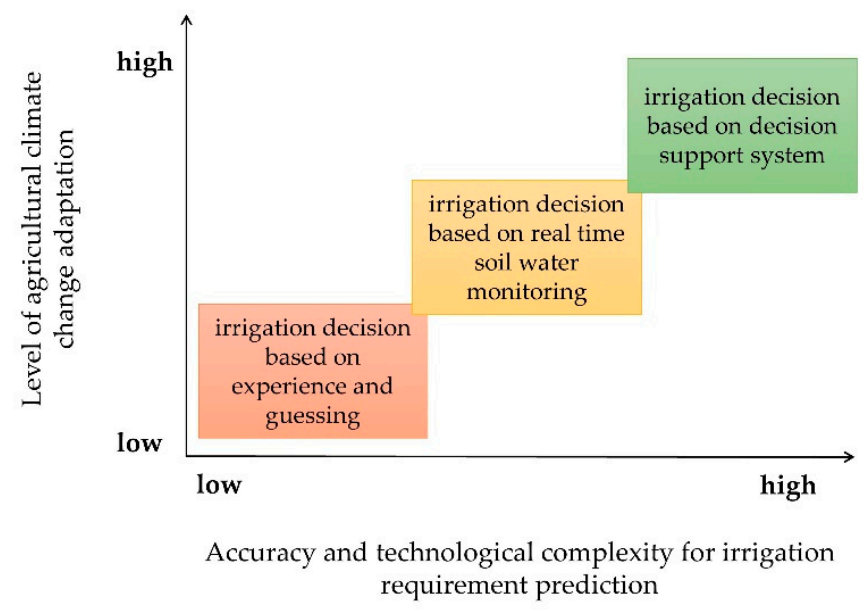

Figure 4. Degree of agricultural climate change adaptation defined in terms of the technological complexity required to predict irrigation requirements.

All farmers provided feedback on their experience of using the IDSS during their three-weekly telephone conversations in 2020; $83 \%$ report using the IDSS and $71 \%$ report regularly viewing soil-moisture status; $49 \%$ claim irrigation duration remained unchanged, while $40 \%$ report irrigating more often for a shorter period of time. Eleven percent of the participating farmers reported that they did not use the IDSS, but that they followed the IDSS reports (no irrigation system installed), while only $6 \%$ ( 2 farmers) were dissatisfied with the IDSS due to inconsistent soil-water measurements and lacked trust in the IDSS. Seventeen percent were partly satisfied, reporting occasional inconsistencies in soil-water measurements or reported irrigation advice overestimating water requirements. A number of factors influence the accuracy, functioning and acceptance of IDSS. The farmers' previous practice was to irrigate once every few days and to apply plant water requirements for several days. It is therefore understandable that for some farmers, daily water recovery appears to be an exaggeration of the water requirement. Nevertheless, most users state that they are very satisfied with the IDSS $(66 \%)$; their confidence in the system is high, the irrigation recommendations are compatible with their observations in the field and the soil water content fits well with irrigation practice. 


\section{Discussion}

There are various approaches to increase water and energy use efficiency and reduce $\mathrm{CO}_{2}$ emissions in irrigated agriculture (Table 2), however their contribution to climate change adaptation varies in different environments and social settings. Regulatory approaches such as requiring abstraction permits designed to regulate water abstractions (Table 2) have a limited impact on achieving higher irrigation efficiency and improved irrigation [8]. Closing open irrigation channels [1] must be accompanied by the installation of flow meters and regular maintenance [2]. At the case study area, the investments in modernization of large irrigation systems were identified as a priority in adapting to climate change [2]. However, they showed to be particularly difficult to implement, as they require formation of large network of actors that are not easily established [2]. Purchasing individual irrigation equipment requires a smaller network of actors, which is why it was likely more successful in the past [2]. The two measures enable purchase of soil-water monitoring equipment. However, this option has not yet been fully exploited by farmers, partly due to the inefficient communication of the option to potential users. This suggests that policy options should be better communicated in rural development programs [1]. Particular attention should be directed to finding suitable, low-cost, low-power soil moisture sensors, with factory calibration functions covering a wide range of soil types and automatic temperature correction for reliable measurements [47-54].

Another reason soil-moisture sensors have not yet been introduced on a larger scale is current inaccessibility of IDSS to a wider range of users. Farmers need to be supported with integrated tools (Table 2), such as IDSS in order to improve decision making in the application of individual regulatory and technical approaches and gain greater competence in irrigation planning. Implementation of IDSSs face similar challenges [8-12,55]. The Vipava Valley process indicates poor data on irrigation system capacity and an irregular control of water delivery on the farm. The latter indicates that while farmers are willing to implement the IDSS, they may not be able to do so if their water supply is limited.

Vipava Valley's approach to implementing IDSS is similar to that of [33], where the development of IDSS closely involved farmers, as suggested by [16]. Workshops are necessary to provide farmers with relevant knowledge on how IDSS works. In addition, a detailed technical inventory was developed in collaboration with the farmers to convert net irrigation demand into irrigation duration in order to provide farmers with practical advice on irrigation planning. However, this proved to be particularly difficult during the implementation of IDSS, as farmers had little knowledge of the technical characteristics of their irrigation equipment. The evaluation of agricultural practices was followed by the determination of the plant water requirements, soil analysis and the installation of soil moisture sensors. The IDSS processes field data and produces graphs and diagrams that allow users to access daily irrigation needs via electronic devices on a daily basis [13]. Farmers gradually started to use IDSS, in line with the results of [4], suggesting that increased irrigation efficiency by changing farmers' behavior through the introduction of IDSS will improve the resilience of agriculture to climate change only after the initial IDSS implementation phase of about five years. The process also shows that optimized irrigation scheduling using IDSS to further reduce water and energy consumption and CO2 emissions is only possible if systemic support is offered on the farm [1,3-7]. To evaluate the success of the IDSS introduced, future research should extend its focus to yield and compare irrigation planning practices of farmers with and without irrigation advice. The IDSS evaluation could be improved by the integration of water meters but would still have to include individual consultation with farmers, as their practice will change over the years. Some of the more technical factors that influence the accuracy, functioning and acceptance of IDSS are the accuracy of the soil moisture measurement; errors caused by the way the soil moisture probe is installed (air pocket); the degree to which the position and depth of the soil moisture probe is able to capture general soil-water retention properties for a larger area of operation (e.g., orchard); the accuracy of the phenophase at the time of calculating daily irrigation requirements and the precipitation and ET0 forecast. Apart from the more technical factors that influence IDSS acceptance, the perception of farmers plays an important role. Sometimes only 
installation of additional soil-moisture sensors (and in some cases rain gauges) will increase the trust in measurements.

Table 2. Policy options to achieve higher irrigation efficiency and greater agricultural resilience to climate change.

\begin{tabular}{cc}
\hline Measures & Impact and Expected Challenges \\
\hline & Regulatory and Technical Measures \\
\hline
\end{tabular}

Applying abstraction permits, permitted abstraction limits

Setting out minimum practice for irrigation water use efficiency

Systematic replacement of open channel and gravity systems with pressurized irrigation systems

Incentives and obligatory installation of irrigation and flow meters

Systems for the regular maintenance of irrigation systems

Incentives, purchase and installation of soil-water monitoring equipment
- Limited impact in environments where charges and/or tariffs for irrigation water are low

- Mostly voluntarily, sometimes assigned to water use permission abstraction limits and of limited impact when on-farm control is absent or irregular

- $\quad$ Limited impact where irrigation systems were designed and built from the beginning as drip and sprinkler and pressurized irrigation systems

- High efficiency where installation of irrigation meters and flow meters have not yet been installed

- $\quad$ Efficient where irrigation systems were designed and built from the start as pressurized irrigation systems, but these require modernization pursuant to irregular maintenance in the past

- High potential to increase irrigation efficiency if combined with expert installation, use and maintenance on field support

\begin{tabular}{|c|c|}
\hline \multicolumn{2}{|c|}{ Farmer Empowerment and Innovation Support System } \\
\hline $\begin{array}{l}\text { Systematic training and first-hand } \\
\text { irrigation planning experience }\end{array}$ & $\begin{array}{l}\text { - Professional support for farmers beyond technical information } \\
\text { and assistance }\end{array}$ \\
\hline $\begin{array}{l}\text { Ongoing assessment of new technology } \\
\text { usefulness and inclusion of farmers at all } \\
\text { stages of the innovation process }\end{array}$ & $\begin{array}{l}\text { - The evaluation of technology involves economic indicators. Farmers } \\
\text { are treated as co-creators of project knowledge }\end{array}$ \\
\hline $\begin{array}{l}\text { Setting up multidisciplinary agricultural } \\
\text { innovation support teams }\end{array}$ & - The infrastructure platform enables mutual knowledge exchange \\
\hline \multicolumn{2}{|c|}{ Integrated Tools to Improve Irrigation Scheduling } \\
\hline Facilitating IDSS uptake & $\begin{array}{l}\text { - High impact and crucial IDSS requirement because uptake } \\
\text { is technically complex, requiring significant change in farmer } \\
\text { irrigation behavior }\end{array}$ \\
\hline $\begin{array}{l}\text { Technical requirement protocols to } \\
\text { access IDSS portal }\end{array}$ & $\begin{array}{l}\text { - High impact because it enables farmer access to IDSS using } \\
\text { tested and reliable equipment that provides the necessary IDSS } \\
\text { support data }\end{array}$ \\
\hline $\begin{array}{l}\text { Making IDSS use mandatory for all } \\
\text { irrigation systems located in climate } \\
\text { change prone agricultural areas }\end{array}$ & $\begin{array}{l}\text { - Limited where IDSS is not available to farmers, but of potentially } \\
\text { high impact once the tools are available }\end{array}$ \\
\hline
\end{tabular}

Financial incentives for the technical modernization of farms are likely to fail unless a sufficient innovation support system is in place to enable farmers to use these advanced tools. Greater emphasis should be placed on farmers' motivations, needs and expectations including professional support beyond technical information and assistance $[17,18]$. Willingness of farmers to innovate depends on 
a number of conditions. The process of putting innovation into practice in agriculture shows that psychological and socioeconomic factors related to communication between different stakeholders often present greater barriers than those related to technological issues [16,19-21]. Aspects such as farmers' motivation, attitudes, cultural capital including knowledge, skills and access to information play a role in the introduction of new technologies to mitigate climate change $[18,22,23]$. Farmers are motivated by the expectation of lower input costs, higher crop productivity and financial benefits and discouraged from using this type of technology by the perception of risks and uncertainties [56,57]. Their involvement in all phases of the innovation process is therefore necessary to better address the complexities of introducing innovation in agriculture $[16,17,24,25]$.

Farmers must be treated as co-creators of project knowledge, not just as implementers. It is also suggested that discussion with farmers should take place through personal contact and farm visits, which is a necessary condition for creating and maintaining trust between farmers and experts. All this diversifies and increases the expert workload, not only those in agriculture and irrigation, but also social researchers and marketing specialists [16]. The extension service, that traditionally was the main actor in transferring innovation into practice, is now among many [21,26-28]. Consequently, future agricultural innovation policy should extend its actions beyond financial measures to those related to facilitating the establishment of multidisciplinary agricultural innovation teams and the development of transparent institutional frameworks that define responsibilities at the different stages of the innovation process (Table 2).

\section{Conclusions}

We used a case study approach to demonstrate IDSS establishment in a climate change prone agricultural area with the aim of identifying and discussing alternative policy options to adapt agriculture to climate change and increase irrigation efficiency. A limitation of this study is that it lacks clarity in terms of how the described IDSS will develop once the project ends. Previous studies focusing on IDSS establishment indicate that a shortfall in permanent user support for farmers represents one of the main obstacles to IDSS sustainability. A more facilitated approach for implementing integrated tools to improve irrigation efficiency is recommended. Nevertheless, successful implementation remains challenging as optimal stakeholder involvement has not been established or financially supported at the systemic level. Even so, the study provides stakeholders, such as the farmer extension service, local government, ministries and experts, with detailed information on which policy options and mechanism are available to establish higher water and energy use efficiency and reduce irrigated food production $\mathrm{CO}_{2}$ emissions. Future IDSS success depends on stakeholder ability to impose a strong implementation program at the national level. As the results of our case study suggest, future research should focus on developing facilitation procedures and mechanisms for implementing IDSS that take into account a multiactor approach.

Author Contributions: Conceptualization, R.C., L.H. and M.P.; data curation, R.C., L.H., U.P. and Š.Ž.; formal analysis, R.C., L.H., U.P. and Š.Ž.; funding acquisition, L.H. and M.P.; investigation, R.C., U.P. and Š.Ž.; methodology, R.C., L.H., U.P., Š.Ž. and M.P.; project administration, R.C., Š.Ž. and M.P.; resources, M.P.; software, L.H.; supervision, M.P.; validation, R.C., L.H. and U.P.; visualization, R.C. and L.H.; writing-original draft, R.C.; writing—review \& editing, R.C., M.Č.-I., L.H., U.P., Š.Ž. and M.P. All authors have read and agreed to the published version of the manuscript.

Funding: This research was funded by EU LIFE Project Adapting to the Impacts of Climate Change in the Vipava Valley (LIFE ViVaCCAdapt), Grant Number LIFE15 CCA/SI/ 000,070 (http://www.life-vivaccadapt.si/en/) and by the European Agricultural Fund for Rural Development and the Republic of Slovenia, Grant Number 33,133-1005/2018/19 (EIP PRO-PRIDELAVA).

Acknowledgments: The authors would like to express their appreciation and gratitude to (i) the participating farmers for their patience and willingness to test and apply new tools for adaptation to climate change, (ii) employees of Municipality of Ajdovščina and Regional Development Agency ROD Ajdovščina for their motivated participation in coordination and implementation of the IDSS in the Vipava Valley (Slovenia) and (iii) Slovenian Environment Agency for sharing the water-balance model IRRFIB and actively contributing the uptake of IDSS at the national level. 
Conflicts of Interest: The authors declare no conflict of interest.

\section{Appendix A}

Table A1. Crops included in the irrigation-decision support system (IDSS) experimental implementation by area (ha) and irrigation technology (drip irrigation, micro-irrigation, high stable sprinklers, low stable sprinklers).

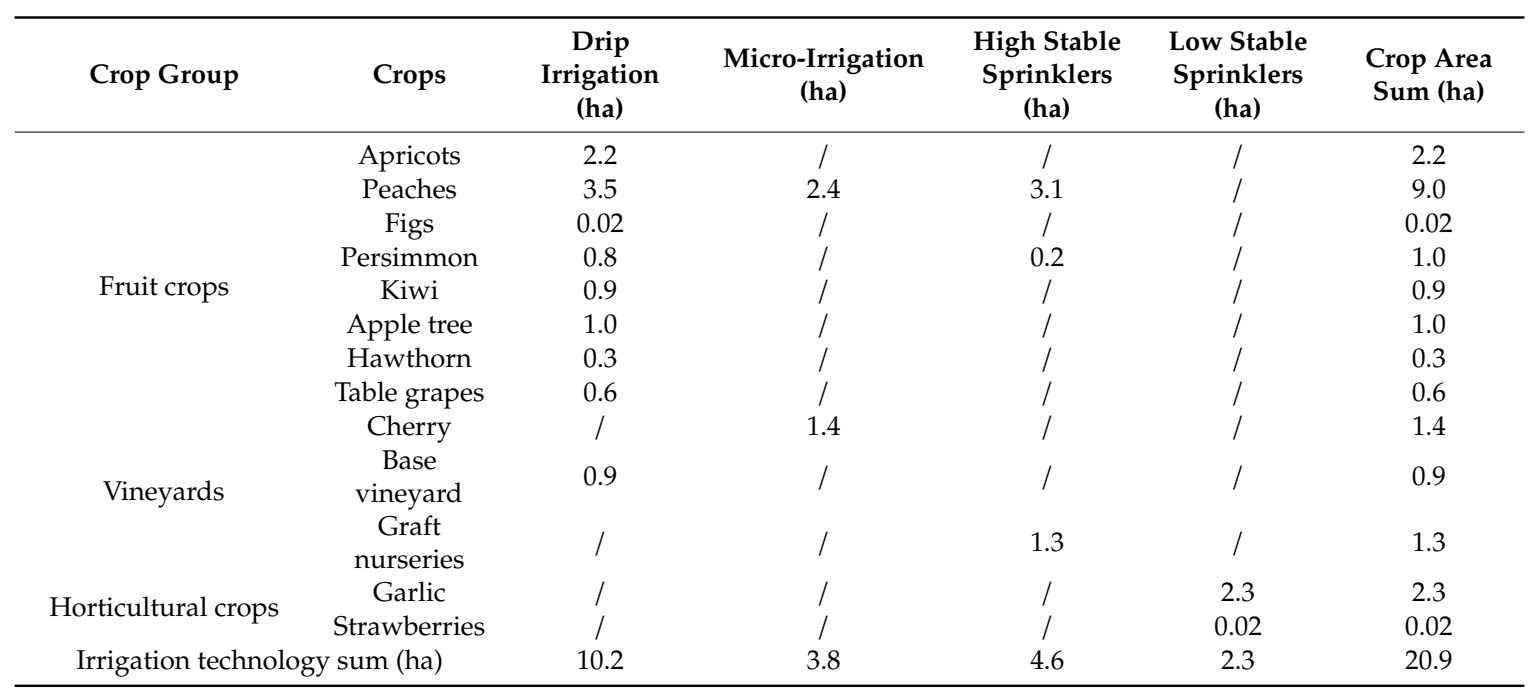

Table A2. On farm soil texture (soil sample taken near the soil moisture sensor).

\begin{tabular}{|c|c|c|c|c|}
\hline Soil Sample Number & Sand $(\%)$ & Clay (\%) & Silt (\%) & Texture Class \\
\hline 1 & 22 & 28 & 50 & clay loam \\
\hline 2 & 19 & 30 & 51 & silty clay loam \\
\hline 3 & 33 & 13 & 54 & silt loam \\
\hline 4 & 30 & 18 & 52 & silt loam \\
\hline 5 & 32 & 14 & 54 & silt loam \\
\hline 6 & 40 & 9 & 51 & silt loam \\
\hline 7 & 14 & 26 & 60 & silt loam \\
\hline 8 & 30 & 12 & 58 & silt loam \\
\hline 9 & 24 & 18 & 58 & silt loam \\
\hline 10 & 14 & 25 & 61 & silt loam \\
\hline 11 & 34 & 18 & 48 & loam \\
\hline 12 & 27 & 22 & 51 & loam \\
\hline 13 & 12 & 28 & 60 & silty clay loam \\
\hline 14 & 34 & 12 & 54 & silt loam \\
\hline 16 & 31 & 15 & 54 & silt loam \\
\hline 17 & 18 & 25 & 57 & silt loam \\
\hline 18 & 16 & 24 & 60 & silt loam \\
\hline 19 & 37 & 8 & 55 & silt loam \\
\hline 20 & 15 & 24 & 61 & silt loam \\
\hline 21 & 33 & 14 & 53 & silt loam \\
\hline 22 & 32 & 12 & 56 & silt loam \\
\hline 23 & 15 & 22 & 63 & silt loam \\
\hline 24 & 44 & 11 & 45 & loam \\
\hline 25 & 14 & 25 & 61 & silt loam \\
\hline 26 & 47 & 19 & 34 & loam \\
\hline 27 & 15 & 28 & 57 & silty clay loam \\
\hline 28 & 10 & 20 & 70 & silt loam \\
\hline 29 & 21 & 35 & 44 & clay loam \\
\hline 30 & 32 & 21 & 47 & loam \\
\hline 32 & 29 & 10 & 61 & silt loam \\
\hline 33 & 29 & 11 & 60 & silt loam \\
\hline 34 & 10 & 23 & 67 & silt loam \\
\hline 35 & 15 & 24 & 61 & silt loam \\
\hline
\end{tabular}


Table A3. Overview of crops and soil-water retention properties at farm level.

\begin{tabular}{|c|c|c|c|}
\hline FARMER_ID & Field Capacity & Wilting Point & Crop \\
\hline 1 & 32 & 12 & peach \\
\hline 2 & 42 & 15 & apricot \\
\hline 3 & 46 & 20 & peach \\
\hline 4 & 37 & 17 & graft nursery \\
\hline 5 & 45 & 21 & cherry \\
\hline 6 & 45 & 13 & peach \\
\hline 7 & 53 & 25 & figs \\
\hline 8 & 38 & 18 & peach \\
\hline 9 & 32 & 20 & persimmon \\
\hline 10 & 35 & 16 & peach \\
\hline 11 & 39 & 18 & peach \\
\hline 12 & 45 & 16 & table grapes \\
\hline 13 & 40 & 17 & persimmon \\
\hline 14 & 41 & 20 & persimmon \\
\hline 15 & 38 & 10 & graft nursery \\
\hline 16 & 45 & 19 & kiwi fruit \\
\hline 17 & 45 & 20 & peach \\
\hline 18 & 32 & 12 & peach \\
\hline 19 & 31 & 15 & peach \\
\hline 20 & 42 & 12 & hawthorn \\
\hline 21 & 40 & 15 & kiwi fruit \\
\hline 22 & 40 & 10 & strawberry \\
\hline 23 & 40 & 19 & peach \\
\hline 24 & 40 & 15 & kiwi fruit \\
\hline 25 & 42 & 15 & apple tree \\
\hline 26 & 41 & 15 & apple tree \\
\hline 27 & 40 & 18 & graft nursery \\
\hline 28 & 38 & 10 & graft nursery \\
\hline 29 & 35 & 10 & graft nursery \\
\hline 30 & 45 & 15 & graft nursery \\
\hline 31 & 34 & 10 & peach \\
\hline 32 & 38 & 14 & garlic \\
\hline 33 & 41 & 15 & apricot \\
\hline 34 & 39 & 15 & apricot \\
\hline 35 & 41 & 20 & persimmon \\
\hline
\end{tabular}

\section{Appendix B}

Example of a procedure for establishing the relationship between on-farm irrigation equipment, energy requirements and $\mathrm{CO}_{2}$ emissions for drip irrigation.

- total row length $\mathrm{TRl}=\mathrm{nR} * \mathrm{fl} \ldots$ where $\mathrm{TRl}=$ total row length $(\mathrm{m}) \mathrm{nR}=$ number of rows $\mathrm{fl}=$ field length $(\mathrm{m})$

- $\quad$ total row surface TRS $=\mathrm{pW} * \mathrm{TRl} \ldots$ where TRS $=$ total row surface $\left(\mathrm{m}^{2}\right) \mathrm{pW}=$ plant width $(\mathrm{m}) \mathrm{TRl}$ $=$ total row length $(\mathrm{m})$

- $\quad$ irrigation intensity ii $=\mathrm{dC} / \mathrm{A} \ldots$ where $\mathrm{ii}=$ irrigation intensity $(\mathrm{mm} / \mathrm{h}) \mathrm{dC}=$ dripper capacity $(\mathrm{l} / \mathrm{h})$ $\mathrm{A}=$ area covered by one dripper $\left(\mathrm{m}^{2}\right)$

- gross irrigation requirement $\ldots$ where glR = gross irrigation requirement $(\mathrm{mm}) \mathrm{iD}=$ irrigation duration (h) (data from irrigation diaries or field assessment) ii $=$ irrigation intensity $(\mathrm{mm} / \mathrm{h})$

- $\quad$ irrigation efficiency $\mathrm{iE}=\mathrm{Ed} \times \mathrm{WDE} \ldots$ where $\mathrm{iE}=$ irrigation efficiency $\mathrm{VJ} \mathrm{Ed}=$ efficiency of drip irrigation (adopted 0.92)

- $\quad \mathrm{WED}=$ water distribution efficiency (adopted 0.98) $\mathrm{iE}=$ irrigation efficiency Ed $=$ efficiency of drip irrigation (adopted 0.92) WED = water distribution efficiency (adopted 0.98) 
- $\quad$ nett irrigation requirement $\mathrm{nlR}=\mathrm{glR}{ }_{\mathrm{iE}} \mathrm{iE} \ldots$ where $\mathrm{nlR}=$ nett irrigation requirement $(\mathrm{mm}) \mathrm{glR}=$ gross irrigation requirement $(\mathrm{mm}) \mathrm{iE}=$ irrigation efficiency (adopted 0.90$)$

- $\quad$ nett water use NWU $=$ TRS * nlR $\ldots$ where NWU $=$ net water use (l) TRS $=$ total row surface $\left(\mathrm{m}^{2}\right)$ $\mathrm{nlR}=$ net irrigation requirement $(\mathrm{mm})$

- $\quad$ gross water use GWU = TRS * glR ... where GWU = gross water use (l) TRS = total row surface $\left(\mathrm{m}^{2}\right) \mathrm{glR}=$ gross irrigation requirement $(\mathrm{mm})$

- energy consumption $\mathrm{EC}=\mathrm{ps} * \mathrm{iD} \ldots$ where $\mathrm{EC}=$ energy consumption $(\mathrm{kWh}) \mathrm{ps}=$ pump strength $(\mathrm{kW}) \mathrm{iD}=$ irrigation duration $(\mathrm{h})$

- $\mathrm{CO} 2$ emission $\mathrm{EMCO}_{2}=\mathrm{EC} * \mathrm{f} \ldots$ where $\mathrm{EMCO}_{2}=$ emissions of $\mathrm{CO}_{2}\left(\mathrm{kgCO}_{2}\right) \mathrm{EC}=$ energy consumption $(\mathrm{kWh}) \mathrm{f}=$ emission factor $\left(\mathrm{kgCO}_{2} / \mathrm{kWh}\right)$ (adopted natural gas $=0.20$, electricity $=$ 0.27 ; gasoline 0.25 ; diesel $=0.27$ )

\section{Appendix C}

Appendix $C$ focuses farm level overview of yearly water and energy consumption, water and energy savings and generation and possible reduction of $\mathrm{CO}_{2}$ emission if irrigation practice is optimized by implementing two irrigation strategies (i) replenishing soil water content to FC and (ii) replenishing to $85 \%$ of reservoir (FC-WP):

- Net irrigation requirement ( $\mathrm{mm}$ ) (Table A4)—taking into account phenophases and soil-water retention properties at farm level by replenishing soil water content to (i) FC and (ii) to $85 \%$ capacity (FC-WP);

- Gross irrigation requirement $(\mathrm{mm})$ (Table A5)—taking into account irrigation equipment at farm level by replenishing soil water content to (i) FC and (ii) to $85 \%$ capacity (FC-WP);

- Gross irrigation requirement $\left(\mathrm{m}^{3}\right)$ (Table A6) - taking into account irrigation equipment at farm level by replenishing soil water content to (i) FC and (ii) to $85 \%$ capacity (FC-WP);

- Irrigation duration (h) (Table A7) - taking into account irrigation equipment at farm level by replenishing soil water content to (i) FC and (ii) to $85 \%$ capacity (FC-WP);

- Absolute water savings (m3) (Table A8) - if irrigation practice is optimized by replenishing soil water content to $85 \%$ capacity (FC-WP) instead to FC;

- Relative water savings (\%) (Table A8) - if irrigation practice is optimized by replenishing soil water content to $85 \%$ capacity (FC-WP) instead to FC;

- Energy use (kWh) (Table A9) — taking into account irrigation equipment at farm level by replenishing soil water content to (i) FC and (ii) to $85 \%$ capacity (FC-WP);

- Absolute energy savings ( $\mathrm{kWh}$ ) (Table A10)—if irrigation practice is optimized by replenishing soil water content to $85 \%$ capacity (FC-WP) instead to FC;

- $\quad$ Relative energy savings (\%) (Table A10)—if irrigation practice is optimized by replenishing soil water content to $85 \%$ capacity (FC-WP) instead to FC;

- $\mathrm{CO}_{2}$ emission generated by irrigation $(\mathrm{kg})$ (Table A11)—-taking into account irrigation equipment at farm level by replenishing soil water content to (i) FC and (ii) to $85 \%$ capacity (FC-WP);

- Absolute $\mathrm{CO}_{2}$ emission reduction (kg) (Table A12)-if replenishing soil water content to 85\% capacity (FC-WP) instead to FC;

- Relative $\mathrm{CO}_{2}$ emission reduction (\%) (Table A12)—if replenishing soil water content to 85\% capacity (FC-WP) instead to FC. 
Table A4. Yearly net irrigation requirement (mm) at farm level.

\begin{tabular}{|c|c|c|c|c|c|c|}
\hline \multirow{2}{*}{ Farmer_Id } & \multicolumn{6}{|c|}{ Net Irrigation Requirement $(\mathrm{mm})$-IRRFIB } \\
\hline & $2017-100 \%$ & $2017-85 \%$ & $2018-100 \%$ & $2018-85 \%$ & $2019-100 \%$ & $2019-85 \%$ \\
\hline 1 & 647.21 & 509.41 & 551.21 & 418.72 & 609.84 & 488.73 \\
\hline 2 & 547.47 & 414.09 & 482.79 & 324.91 & 540.67 & 420.33 \\
\hline 3 & 547.47 & 417.69 & 482.79 & 329.11 & 540.67 & 422.58 \\
\hline 4 & 195.32 & 98.74 & 136.97 & 42.53 & 182.90 & 130.01 \\
\hline 5 & 609.04 & 492.66 & 552.91 & 442.61 & 573.05 & 460.42 \\
\hline 6 & 647.21 & 505.46 & 551.21 & 376.20 & 609.84 & 449.55 \\
\hline 7 & 390.30 & 250.98 & 362.12 & 200.72 & 380.81 & 281.72 \\
\hline 8 & 647.21 & 509.41 & 551.21 & 418.72 & 609.84 & 488.73 \\
\hline 9 & 589.58 & 475.28 & 527.21 & 417.33 & 570.71 & 463.29 \\
\hline 10 & 547.47 & 421.25 & 482.79 & 356.51 & 540.67 & 439.87 \\
\hline 11 & 647.21 & 516.36 & 551.21 & 413.92 & 609.84 & 484.53 \\
\hline 12 & 352.14 & 194.01 & 316.04 & 119.67 & 352.92 & 230.90 \\
\hline 13 & 589.58 & 442.12 & 527.21 & 370.26 & 570.71 & 432.88 \\
\hline 14 & 672.39 & 535.98 & 578.64 & 415.81 & 628.10 & 478.18 \\
\hline 15 & 228.70 & 138.92 & 183.70 & 83.31 & 215.93 & 166.96 \\
\hline 16 & 531.71 & 384.83 & 495.91 & 332.09 & 519.46 & 396.15 \\
\hline 17 & 547.47 & 413.20 & 482.79 & 333.31 & 540.67 & 424.98 \\
\hline 18 & 547.47 & 415.25 & 482.79 & 354.31 & 540.67 & 436.98 \\
\hline 19 & 647.21 & 533.41 & 551.21 & 436.07 & 609.84 & 492.53 \\
\hline 20 & 596.75 & 469.47 & 549.07 & 426.21 & 574.45 & 466.12 \\
\hline 21 & 531.71 & 378.74 & 495.91 & 336.59 & 519.46 & 398.40 \\
\hline 22 & 136.84 & 106.46 & 98.13 & 68.11 & 82.00 & 41.62 \\
\hline 23 & 547.47 & 422.21 & 482.79 & 350.11 & 540.67 & 434.58 \\
\hline 24 & 531.71 & 378.74 & 495.91 & 336.59 & 519.46 & 398.40 \\
\hline 25 & 596.75 & 470.90 & 549.07 & 435.79 & 574.45 & 471.62 \\
\hline 26 & 596.75 & 461.75 & 549.07 & 439.39 & 574.45 & 473.87 \\
\hline 27 & 195.32 & 92.74 & 136.97 & 38.48 & 182.90 & 127.01 \\
\hline 28 & 228.70 & 138.92 & 183.70 & 83.31 & 215.93 & 166.96 \\
\hline 29 & 228.70 & 147.59 & 183.70 & 90.96 & 215.93 & 163.10 \\
\hline 30 & 228.70 & 146.47 & 183.70 & 78.20 & 215.93 & 165.11 \\
\hline 31 & 547.47 & 417.40 & 482.79 & 337.51 & 540.67 & 427.38 \\
\hline 32 & 367.72 & 329.35 & 233.36 & 187.08 & 309.25 & 263.64 \\
\hline 33 & 547.47 & 417.69 & 482.79 & 329.11 & 540.67 & 422.58 \\
\hline 34 & 547.47 & 417.40 & 482.79 & 337.51 & 540.67 & 427.38 \\
\hline 35 & 589.58 & 451.12 & 527.21 & 370.56 & 570.71 & 436.89 \\
\hline Average & 490.04 & 369.03 & 427.65 & 298.05 & 470.42 & 367.83 \\
\hline Sum & $17,151.28$ & $12,916.02$ & $14,967.68$ & $10,431.59$ & $16,464.72$ & $12,874.00$ \\
\hline
\end{tabular}


Table A5. Yearly gross irrigation requirement $(\mathrm{mm})$ at farm level by replenishing soil water content to (i) FC and (ii) to $85 \%$ capacity (FC-WP).

\begin{tabular}{|c|c|c|c|c|c|c|}
\hline \multirow[t]{2}{*}{ Farmer_Id } & \multicolumn{6}{|c|}{ Gross Irrigation Requirement (mm) } \\
\hline & $2017-100 \%$ & $2017-85 \%$ & $2018-100 \%$ & $2018-85 \%$ & $2019-100 \%$ & $2019-85 \%$ \\
\hline 1 & 995.71 & 783.70 & 848.02 & 644.18 & 938.21 & 751.90 \\
\hline 2 & 595.08 & 450.10 & 524.77 & 353.16 & 587.68 & 456.88 \\
\hline 3 & 595.08 & 454.01 & 524.77 & 357.73 & 587.68 & 459.33 \\
\hline 4 & 300.49 & 151.91 & 210.72 & 65.44 & 281.38 & 200.02 \\
\hline 5 & 676.71 & 547.40 & 614.35 & 491.78 & 636.72 & 511.58 \\
\hline 6 & 719.12 & 561.63 & 612.46 & 418.00 & 677.60 & 499.50 \\
\hline 7 & 424.24 & 272.80 & 393.61 & 218.17 & 413.92 & 306.22 \\
\hline 8 & 995.71 & 783.70 & 848.02 & 644.18 & 938.21 & 751.90 \\
\hline 9 & 655.09 & 528.09 & 585.79 & 463.70 & 634.13 & 514.76 \\
\hline 10 & 608.30 & 468.06 & 536.43 & 396.12 & 600.74 & 488.74 \\
\hline 11 & 995.71 & 794.41 & 848.02 & 636.80 & 938.21 & 745.44 \\
\hline 12 & 382.76 & 210.88 & 343.52 & 130.07 & 383.61 & 250.98 \\
\hline 13 & 640.85 & 480.57 & 573.06 & 402.46 & 620.34 & 470.52 \\
\hline 14 & 1034.45 & 824.59 & 890.22 & 639.70 & 966.31 & 735.66 \\
\hline 15 & 248.58 & 151.00 & 199.67 & 90.55 & 234.71 & 181.48 \\
\hline 16 & 577.95 & 418.30 & 539.03 & 360.96 & 564.63 & 430.59 \\
\hline 17 & 595.08 & 449.13 & 524.77 & 362.29 & 587.68 & 461.93 \\
\hline 18 & 595.08 & 451.36 & 524.77 & 385.12 & 587.68 & 474.98 \\
\hline 19 & 995.71 & 820.63 & 848.02 & 670.88 & 938.21 & 757.74 \\
\hline 20 & 648.65 & 510.29 & 596.82 & 463.28 & 624.40 & 506.65 \\
\hline 21 & 577.95 & 411.67 & 539.03 & 365.85 & 564.63 & 433.04 \\
\hline 22 & I & / & / & I & / & / \\
\hline 23 & 608.30 & 469.12 & 536.43 & 389.01 & 600.74 & 482.87 \\
\hline 24 & 577.95 & 411.67 & 539.03 & 365.85 & 564.63 & 433.04 \\
\hline 25 & 648.65 & 511.85 & 596.82 & 473.69 & 624.40 & 512.63 \\
\hline 26 & 648.65 & 501.91 & 596.82 & 477.60 & 624.40 & 515.08 \\
\hline 27 & 300.49 & 142.68 & 210.72 & 59.21 & 281.38 & 195.40 \\
\hline 28 & / & I & I & / & / & I \\
\hline 29 & 248.58 & 160.43 & 199.67 & 98.86 & 234.71 & 177.28 \\
\hline 30 & / & / & / & / & / & / \\
\hline 31 & 608.30 & 463.77 & 536.43 & 375.01 & 600.74 & 474.87 \\
\hline 32 & 574.56 & 514.61 & 364.63 & 292.32 & 483.21 & 411.93 \\
\hline 33 & 595.08 & 454.01 & 524.77 & 357.73 & 587.68 & 459.33 \\
\hline 34 & 595.08 & 453.69 & 524.77 & 366.86 & 587.68 & 464.54 \\
\hline 35 & 640.85 & 490.35 & 573.06 & 402.79 & 620.34 & 474.89 \\
\hline AVERAGE & 622.02 & 471.82 & 541.53 & 381.85 & 597.39 & 468.49 \\
\hline SUM & $19,904.76$ & $15,098.32$ & $17,329.02$ & $12,219.35$ & $19,116.61$ & $14,991.69$ \\
\hline
\end{tabular}


Table A6. Yearly gross irrigation requirement $\left(\mathrm{m}^{3}\right)$ at farm level by replenishing soil water content to (i) FC and (ii) to $85 \%$ capacity (FC-WP).

\begin{tabular}{|c|c|c|c|c|c|c|}
\hline \multirow[t]{2}{*}{ Farmer_Id } & \multicolumn{6}{|c|}{ Gross Irrigation Requirement $\left(\mathrm{m}^{3}\right)$} \\
\hline & $2017-100 \%$ & $2017-85 \%$ & $2018-100 \%$ & $2018-85 \%$ & $2019-100 \%$ & $2019-85 \%$ \\
\hline 1 & 4854.08 & 3820.55 & 4134.10 & 3140.40 & 4573.78 & 3665.51 \\
\hline 2 & 542.00 & 409.95 & 477.96 & 321.66 & 535.26 & 416.13 \\
\hline 3 & 1543.87 & 1177.89 & 1361.47 & 928.08 & 1524.69 & 1191.67 \\
\hline 4 & 976.58 & 493.71 & 684.84 & 212.67 & 914.49 & 650.05 \\
\hline 5 & 2984.31 & 2414.04 & 2709.27 & 2168.76 & 2807.94 & 2256.05 \\
\hline 6 & 657.83 & 513.75 & 560.25 & 382.37 & 619.84 & 456.92 \\
\hline 7 & 46.84 & 30.12 & 43.45 & 24.09 & 45.70 & 33.81 \\
\hline 8 & 3624.38 & 2852.68 & 3086.80 & 2344.83 & 3415.09 & 2736.91 \\
\hline 9 & 578.02 & 465.97 & 516.88 & 409.15 & 559.53 & 454.21 \\
\hline 10 & 2189.89 & 1685.00 & 1931.16 & 1426.04 & 2162.67 & 1759.46 \\
\hline 11 & 4659.92 & 3717.82 & 3968.74 & 2980.22 & 4390.83 & 3488.65 \\
\hline 12 & 274.67 & 151.32 & 246.51 & 93.34 & 275.28 & 180.11 \\
\hline 13 & 1179.16 & 884.25 & 1054.42 & 740.52 & 1141.43 & 865.76 \\
\hline 14 & 1371.68 & 1093.41 & 1180.43 & 848.24 & 1281.33 & 975.49 \\
\hline 15 & 808.21 & 490.95 & 649.19 & 294.42 & 763.11 & 590.05 \\
\hline 16 & 1131.49 & 818.92 & 1055.29 & 706.68 & 1105.41 & 843.00 \\
\hline 17 & 4730.15 & 3570.02 & 4171.30 & 2879.78 & 4671.38 & 3671.82 \\
\hline 18 & 923.26 & 700.28 & 814.18 & 597.50 & 911.78 & 736.92 \\
\hline 19 & 6925.16 & 5707.46 & 5897.99 & 4665.94 & 6525.26 & 5270.09 \\
\hline 20 & 1485.92 & 1168.98 & 1367.19 & 1061.27 & 1430.37 & 1160.63 \\
\hline 21 & 370.60 & 263.98 & 345.65 & 234.60 & 362.06 & 277.68 \\
\hline 22 & I & / & / & / & / & I \\
\hline 23 & 965.74 & 744.77 & 851.64 & 617.59 & 953.74 & 766.60 \\
\hline 24 & 2977.60 & 2120.94 & 2777.09 & 1884.88 & 2908.97 & 2231.02 \\
\hline 25 & 319.56 & 252.17 & 294.03 & 233.37 & 307.62 & 252.55 \\
\hline 26 & 1432.21 & 1108.21 & 1317.77 & 1054.54 & 1378.67 & 1137.30 \\
\hline 27 & 1562.53 & 741.93 & 1095.74 & 307.87 & 1463.19 & 1016.08 \\
\hline 28 & I & / & / & / & I & I \\
\hline 29 & 2273.23 & 1467.08 & 1825.96 & 904.10 & 2146.37 & 1621.18 \\
\hline 30 & I & / & / & / & / & / \\
\hline 31 & 3941.80 & 3005.26 & 3476.08 & 2430.06 & 3892.81 & 3077.13 \\
\hline 32 & 8457.58 & 7575.09 & 5367.37 & 4302.93 & 7112.83 & 6063.62 \\
\hline 33 & 2978.25 & 2272.24 & 2626.37 & 1790.35 & 2941.24 & 2298.83 \\
\hline 34 & 427.03 & 325.57 & 376.58 & 263.26 & 421.72 & 333.36 \\
\hline 35 & 353.75 & 270.67 & 316.33 & 222.34 & 342.43 & 262.14 \\
\hline AVERAGE & 2110.85 & 1634.84 & 1768.19 & 1264.75 & 1996.46 & 1585.65 \\
\hline SUM & $67,547.26$ & $52,314.98$ & $56,582.01$ & $40,471.85$ & $63,886.79$ & $50,740.74$ \\
\hline
\end{tabular}


Table A7. Yearly irrigation duration (h) at farm level by replenishing soil water content to (i) FC and (ii) to $85 \%$ capacity (FC-WP).

\begin{tabular}{|c|c|c|c|c|c|c|}
\hline \multirow[t]{2}{*}{ Farmer_Id } & \multicolumn{6}{|c|}{ Irrigation Duration (h) } \\
\hline & $2017-100 \%$ & $2017-85 \%$ & $2018-100 \%$ & $2018-85 \%$ & $2019-100 \%$ & $2019-85 \%$ \\
\hline 1 & 161.80 & 127.35 & 137.80 & 104.68 & 152.46 & 122.18 \\
\hline 2 & 684.34 & 517.61 & 603.49 & 406.13 & 675.84 & 525.42 \\
\hline 3 & 273.74 & 208.85 & 241.39 & 164.55 & 270.33 & 211.29 \\
\hline 4 & 217.02 & 109.71 & 152.19 & 47.26 & 203.22 & 144.46 \\
\hline 5 & 49.12 & 39.73 & 44.59 & 35.69 & 46.21 & 37.13 \\
\hline 6 & 75.26 & 58.77 & 64.09 & 43.74 & 70.91 & 52.27 \\
\hline 7 & 130.10 & 83.66 & 120.71 & 66.91 & 126.94 & 93.91 \\
\hline 8 & 269.67 & 212.25 & 229.67 & 174.47 & 254.10 & 203.64 \\
\hline 9 & 203.30 & 163.89 & 181.80 & 143.91 & 196.80 & 159.75 \\
\hline 10 & 182.49 & 140.42 & 160.93 & 118.84 & 180.22 & 146.62 \\
\hline 11 & 294.19 & 234.71 & 250.55 & 188.15 & 277.20 & 220.24 \\
\hline 12 & 52.56 & 28.96 & 47.17 & 17.86 & 52.68 & 34.46 \\
\hline 13 & 535.98 & 401.93 & 479.28 & 336.60 & 518.83 & 393.53 \\
\hline 14 & 137.22 & 109.38 & 118.09 & 84.86 & 128.18 & 97.59 \\
\hline 15 & 228.70 & 138.92 & 183.70 & 83.31 & 215.93 & 166.96 \\
\hline 16 & 143.71 & 104.01 & 134.03 & 89.75 & 140.39 & 107.07 \\
\hline 17 & 288.14 & 217.47 & 254.10 & 175.43 & 284.56 & 223.67 \\
\hline 18 & 260.70 & 197.74 & 229.90 & 168.72 & 257.46 & 208.09 \\
\hline 19 & 588.37 & 484.92 & 501.10 & 396.43 & 554.40 & 447.76 \\
\hline 20 & 221.02 & 173.88 & 203.36 & 157.86 & 212.76 & 172.64 \\
\hline 21 & 354.48 & 252.49 & 330.61 & 224.39 & 346.31 & 265.60 \\
\hline 22 & I & / & I & I & I & I \\
\hline 23 & 82.95 & 63.97 & 73.15 & 53.05 & 81.92 & 65.85 \\
\hline 24 & 221.55 & 157.81 & 206.63 & 140.24 & 216.44 & 166.00 \\
\hline 25 & 53.76 & 42.42 & 49.47 & 39.26 & 51.75 & 42.49 \\
\hline 26 & 284.17 & 219.88 & 261.46 & 209.24 & 273.55 & 225.65 \\
\hline 27 & 39.06 & 18.55 & 27.39 & 7.70 & 36.58 & 25.40 \\
\hline 28 & / & / & / & / & I & I \\
\hline 29 & 76.23 & 49.20 & 61.23 & 30.32 & 71.98 & 54.37 \\
\hline 30 & I & I & / & I & I & I \\
\hline 31 & 172.16 & 131.26 & 151.82 & 106.13 & 170.02 & 134.40 \\
\hline 32 & 61.29 & 54.89 & 38.89 & 31.18 & 51.54 & 43.94 \\
\hline 33 & 497.70 & 379.72 & 438.90 & 299.19 & 491.52 & 384.16 \\
\hline 34 & 273.74 & 208.70 & 241.39 & 168.75 & 270.33 & 213.69 \\
\hline 35 & 218.36 & 167.08 & 195.26 & 137.25 & 211.38 & 161.81 \\
\hline AVERAGE & 229.15 & 171.88 & 200.44 & 139.12 & 221.65 & 173.50 \\
\hline
\end{tabular}


Table A8. Yearly absolute $\left(\mathrm{m}^{3}\right)$ and relative (\%) water savings at farm level if replenishing soil water content to $85 \%$ capacity (FC-WP) instead to FC.

\begin{tabular}{|c|c|c|c|c|c|c|}
\hline \multirow{2}{*}{ Farmer_Id } & \multicolumn{3}{|c|}{ Absolute Water Savings $\left(\mathrm{m}^{3}\right)$} & \multicolumn{3}{|c|}{ Relative Water Savings (\%) } \\
\hline & 2017 & 2018 & 2019 & 2017 & 2018 & 2019 \\
\hline 1 & 1033.53 & 993.70 & 908.27 & 21.29 & 24.04 & 19.86 \\
\hline 2 & 132.05 & 156.30 & 119.13 & 24.36 & 32.70 & 22.26 \\
\hline 3 & 365.98 & 433.38 & 333.01 & 23.71 & 31.83 & 21.84 \\
\hline 4 & 482.87 & 472.17 & 264.44 & 49.45 & 68.95 & 28.92 \\
\hline 5 & 570.27 & 540.50 & 551.88 & 19.11 & 19.95 & 19.65 \\
\hline 6 & 144.07 & 177.88 & 162.92 & 21.90 & 31.75 & 26.28 \\
\hline 7 & 16.72 & 19.37 & 11.89 & 35.70 & 44.57 & 26.02 \\
\hline 8 & 771.70 & 741.97 & 678.18 & 21.29 & 24.04 & 19.86 \\
\hline 9 & 112.05 & 107.73 & 105.32 & 19.39 & 20.84 & 18.82 \\
\hline 10 & 504.88 & 505.11 & 403.21 & 23.06 & 26.16 & 18.64 \\
\hline 11 & 942.10 & 988.52 & 902.18 & 20.22 & 24.91 & 20.55 \\
\hline 12 & 123.34 & 153.17 & 95.17 & 44.91 & 62.14 & 34.57 \\
\hline 13 & 294.91 & 313.90 & 275.67 & 25.01 & 29.77 & 24.15 \\
\hline 14 & 278.27 & 332.19 & 305.84 & 20.29 & 28.14 & 23.87 \\
\hline 15 & 317.26 & 354.77 & 173.05 & 39.25 & 54.65 & 22.68 \\
\hline 16 & 312.56 & 348.61 & 262.41 & 27.62 & 33.03 & 23.74 \\
\hline 17 & 1160.13 & 1291.52 & 999.55 & 24.53 & 30.96 & 21.40 \\
\hline 18 & 222.98 & 216.67 & 174.86 & 24.15 & 26.61 & 19.18 \\
\hline 19 & 1217.70 & 1232.05 & 1255.17 & 17.58 & 20.89 & 19.24 \\
\hline 20 & 316.94 & 305.91 & 269.74 & 21.33 & 22.38 & 18.86 \\
\hline 21 & 106.62 & 111.05 & 84.38 & 28.77 & 32.13 & 23.31 \\
\hline 22 & I & / & / & / & / & / \\
\hline 23 & 220.97 & 234.05 & 187.14 & 22.88 & 27.48 & 19.62 \\
\hline 24 & 856.66 & 892.21 & 677.95 & 28.77 & 32.13 & 23.31 \\
\hline 25 & 67.39 & 60.66 & 55.06 & 21.09 & 20.63 & 17.90 \\
\hline 26 & 324.00 & 263.22 & 241.38 & 22.62 & 19.98 & 17.51 \\
\hline 27 & 820.60 & 787.88 & 447.11 & 52.52 & 71.90 & 30.56 \\
\hline 28 & I & / & / & l & I & I \\
\hline 29 & 806.15 & 921.86 & 525.19 & 35.46 & 50.49 & 24.47 \\
\hline 30 & / & / & / & / & / & I \\
\hline 31 & 936.54 & 1046.03 & 815.68 & 23.76 & 30.09 & 20.95 \\
\hline 32 & 882.50 & 1064.44 & 1049.21 & 10.43 & 19.83 & 14.75 \\
\hline 33 & 706.01 & 836.03 & 642.40 & 23.71 & 31.83 & 21.84 \\
\hline 34 & 101.46 & 113.32 & 88.37 & 23.76 & 30.09 & 20.95 \\
\hline 35 & 83.07 & 93.99 & 80.29 & 23.48 & 29.71 & 23.45 \\
\hline Average & 476.01 & 503.44 & 410.81 & 26.29 & 32.96 & 22.16 \\
\hline Sum & $15,232.28$ & $16,110.16$ & $13,146.05$ & & & \\
\hline
\end{tabular}


Table A9. Yearly energy use (kWh) due to irrigation at farm level by replenishing soil water content to (i) FC and (ii) to $85 \%$ capacity (FC-WP).

\begin{tabular}{|c|c|c|c|c|c|c|}
\hline \multirow{2}{*}{ Farmer_Id } & \multicolumn{6}{|c|}{ Energy Use (kWh) } \\
\hline & $2017-100 \%$ & $2017-85 \%$ & $2018-100 \%$ & $2018-85 \%$ & $2019-100 \%$ & $2019-85 \%$ \\
\hline 1 & 889.91 & 700.43 & 757.92 & 575.74 & 838.53 & 672.01 \\
\hline 2 & 3421.70 & 2588.07 & 3017.43 & 2030.67 & 3379.18 & 2627.09 \\
\hline 3 & 1122.32 & 856.27 & 989.72 & 674.67 & 1108.37 & 866.29 \\
\hline 4 & 4340.36 & 2194.25 & 3043.73 & 945.20 & 4064.41 & 2889.11 \\
\hline 5 & 245.58 & 198.65 & 222.95 & 178.47 & 231.07 & 185.65 \\
\hline 6 & $15,051.41$ & $11,754.98$ & $12,818.93$ & 8748.85 & $14,182.26$ & $10,454.65$ \\
\hline 7 & 715.56 & 460.13 & 663.89 & 367.98 & 698.15 & 516.49 \\
\hline 8 & 0.00 & 0.00 & 0.00 & 0.00 & 0.00 & 0.00 \\
\hline 9 & 1016.51 & 819.46 & 908.98 & 719.53 & 983.99 & 798.77 \\
\hline 10 & 912.45 & 702.08 & 804.65 & 594.18 & 901.11 & 733.11 \\
\hline 11 & $29,418.67$ & $23,471.09$ & $25,055.17$ & $18,814.54$ & $27,719.88$ & $22,024.29$ \\
\hline 12 & 0.00 & 0.00 & 0.00 & 0.00 & 0.00 & 0.00 \\
\hline 13 & 2143.92 & 1607.72 & 1917.13 & 1346.40 & 2075.32 & 1574.10 \\
\hline 14 & $27,444.53$ & $21,876.85$ & $23,618.04$ & $16,971.66$ & $25,636.81$ & $19,517.57$ \\
\hline 15 & 1143.48 & 694.61 & 918.49 & 416.55 & 1079.66 & 834.82 \\
\hline 16 & 199.75 & 144.57 & 186.30 & 124.76 & 195.15 & 148.82 \\
\hline 17 & 2881.43 & 2174.72 & 2541.00 & 1754.25 & 2845.62 & 2236.73 \\
\hline 18 & 756.03 & 573.44 & 666.71 & 489.28 & 746.64 & 603.45 \\
\hline 19 & $29,418.67$ & $24,245.78$ & $25,055.17$ & $19,821.31$ & $27,719.88$ & $22,387.81$ \\
\hline 20 & 1105.10 & 869.39 & 1016.80 & 789.28 & 1063.79 & 863.18 \\
\hline 21 & 1584.51 & 1128.64 & 1477.81 & 1003.03 & 1547.99 & 1187.22 \\
\hline 22 & I & I & 1 & I & I & I \\
\hline 23 & 199.08 & 153.53 & 175.56 & 127.31 & 196.61 & 158.03 \\
\hline 24 & 1107.74 & 789.04 & 1033.14 & 701.22 & 1082.20 & 829.99 \\
\hline 25 & 268.81 & 212.12 & 247.33 & 196.30 & 258.76 & 212.44 \\
\hline 26 & 0.00 & 0.00 & 0.00 & 0.00 & 0.00 & 0.00 \\
\hline 27 & 234.38 & 111.29 & 164.36 & 46.18 & 219.48 & 152.41 \\
\hline 28 & / & / & / & / & / & / \\
\hline 29 & 381.16 & 245.99 & 306.16 & 151.59 & 359.89 & 271.83 \\
\hline 30 & I & / & I & I & / & I \\
\hline 31 & 860.80 & 656.28 & 759.10 & 530.67 & 850.11 & 671.98 \\
\hline 32 & 306.43 & 274.46 & 194.47 & 155.90 & 257.71 & 219.70 \\
\hline 33 & 2488.51 & 1898.59 & 2194.50 & 1495.95 & 2457.58 & 1920.82 \\
\hline 34 & 1368.68 & 1043.49 & 1206.97 & 843.77 & 1351.67 & 1068.45 \\
\hline 35 & 0.00 & 0.00 & 0.00 & 0.00 & 0.00 & 0.00 \\
\hline Average & 4679.55 & 3658.78 & 3998.66 & 2879.12 & 4430.42 & 3450.96 \\
\hline
\end{tabular}


Table A10. Yearly absolute $\left(\mathrm{m}^{3}\right)$ and relative (\%) energy savings at farm level if replenishing soil water content to $85 \%$ capacity (FC-WP) instead to FC.

\begin{tabular}{|c|c|c|c|c|c|c|}
\hline \multirow{2}{*}{ Farmer_Id } & \multicolumn{3}{|c|}{ Absolute Energy Savings (kWh) } & \multicolumn{3}{|c|}{ Relative Energy Savings (\%) } \\
\hline & 2017 & 2018 & 2019 & 2017 & 2018 & 2019 \\
\hline 1 & 189.48 & 182.18 & 166.52 & 21.29 & 24.04 & 19.86 \\
\hline 2 & 833.63 & 986.76 & 752.09 & 24.36 & 32.70 & 22.26 \\
\hline 3 & 266.05 & 315.05 & 242.08 & 23.71 & 31.83 & 21.84 \\
\hline 4 & 2146.11 & 2098.53 & 1175.30 & 49.45 & 68.95 & 28.92 \\
\hline 5 & 46.93 & 44.48 & 45.42 & 19.11 & 19.95 & 19.65 \\
\hline 6 & 3296.43 & 4070.08 & 3727.61 & 21.90 & 31.75 & 26.28 \\
\hline 7 & 255.43 & 295.91 & 181.66 & 35.70 & 44.57 & 26.02 \\
\hline 8 & 0.00 & 0.00 & 0.00 & I & I & I \\
\hline 9 & 197.06 & 189.46 & 185.22 & 19.39 & 20.84 & 18.82 \\
\hline 10 & 210.37 & 210.46 & 168.00 & 23.06 & 26.16 & 18.64 \\
\hline 11 & 5947.58 & 6240.63 & 5695.59 & 20.22 & 24.91 & 20.55 \\
\hline 12 & 0.00 & 0.00 & 0.00 & / & I & / \\
\hline 13 & 536.20 & 570.74 & 501.21 & 25.01 & 29.77 & 24.15 \\
\hline 14 & 5567.68 & 6646.38 & 6119.24 & 20.29 & 28.14 & 23.87 \\
\hline 15 & 448.86 & 501.94 & 244.84 & 39.25 & 54.65 & 22.68 \\
\hline 16 & 55.18 & 61.54 & 46.33 & 27.62 & 33.03 & 23.74 \\
\hline 17 & 706.71 & 786.74 & 608.89 & 24.53 & 30.96 & 21.40 \\
\hline 18 & 182.59 & 177.43 & 143.19 & 24.15 & 26.61 & 19.18 \\
\hline 19 & 5172.89 & 5233.86 & 5332.07 & 17.58 & 20.89 & 19.24 \\
\hline 20 & 235.71 & 227.51 & 200.61 & 21.33 & 22.38 & 18.86 \\
\hline 21 & 455.87 & 474.78 & 360.76 & 28.77 & 32.13 & 23.31 \\
\hline 22 & I & / & / & / & / & / \\
\hline 23 & 45.55 & 48.25 & 38.58 & 22.88 & 27.48 & 19.62 \\
\hline 24 & 318.70 & 331.92 & 252.21 & 28.77 & 32.13 & 23.31 \\
\hline 25 & 56.69 & 51.03 & 46.32 & 21.09 & 20.63 & 17.90 \\
\hline 26 & 0.00 & 0.00 & 0.00 & I & / & I \\
\hline 27 & 123.09 & 118.18 & 67.07 & 52.52 & 71.90 & 30.56 \\
\hline 28 & I & I & / & / & / & / \\
\hline 29 & 135.17 & 154.57 & 88.06 & 35.46 & 50.49 & 24.47 \\
\hline 30 & I & I & / & I & I & 1 \\
\hline 31 & 204.52 & 228.43 & 178.13 & 23.76 & 30.09 & 20.95 \\
\hline 32 & 31.97 & 38.57 & 38.01 & 10.43 & 19.83 & 14.75 \\
\hline 33 & 589.91 & 698.55 & 536.77 & 23.71 & 31.83 & 21.84 \\
\hline 34 & 325.19 & 363.20 & 283.22 & 23.76 & 30.09 & 20.95 \\
\hline 35 & I & I & 1 & I & / & I \\
\hline Average & 1020.77 & 1119.54 & 979.46 & 26.04 & 32.81 & 21.91 \\
\hline Sum & $28,581.55$ & $31,347.14$ & $27,424.99$ & & & \\
\hline
\end{tabular}


Table A11. Yearly $\mathrm{CO}_{2}$ emission generation due to irrigation $(\mathrm{kg})$ at farm level by replenishing soil water content to (i) FC and (ii) to $85 \%$ capacity (FC-WP).

\begin{tabular}{|c|c|c|c|c|c|c|}
\hline \multirow{2}{*}{ Farmer_Id } & \multicolumn{6}{|c|}{$\mathrm{CO}_{2}$ Emission Generation due to Irrigation $(\mathrm{kg})$} \\
\hline & $2017-100 \%$ & $2017-85 \%$ & $2018-100 \%$ & $2018-85 \%$ & $2019-100 \%$ & $2019-85 \%$ \\
\hline 1 & 240.28 & 189.12 & 204.64 & 155.45 & 226.40 & 181.44 \\
\hline 2 & 923.86 & 698.78 & 814.71 & 548.28 & 912.38 & 709.31 \\
\hline 3 & 280.58 & 214.07 & 247.43 & 168.67 & 277.09 & 216.57 \\
\hline 4 & 1171.90 & 592.45 & 821.81 & 255.21 & 1097.39 & 780.06 \\
\hline 5 & 66.31 & 53.64 & 60.20 & 48.19 & 62.39 & 50.13 \\
\hline 6 & 4063.88 & 3173.84 & 3461.11 & 2362.19 & 3829.21 & 2822.76 \\
\hline 7 & 193.20 & 124.23 & 179.25 & 99.36 & 188.50 & 139.45 \\
\hline 8 & 0.00 & 0.00 & 0.00 & 0.00 & 0.00 & 0.00 \\
\hline 9 & 274.46 & 221.25 & 245.43 & 194.27 & 265.68 & 215.67 \\
\hline 10 & 228.11 & 175.52 & 201.16 & 148.55 & 225.28 & 183.28 \\
\hline 11 & 7943.04 & 6337.19 & 6764.90 & 5079.93 & 7484.37 & 5946.56 \\
\hline 12 & 0.00 & 0.00 & 0.00 & 0.00 & 0.00 & 0.00 \\
\hline 13 & 428.78 & 321.54 & 383.43 & 269.28 & 415.06 & 314.82 \\
\hline 14 & 7410.02 & 5906.75 & 6376.87 & 4582.35 & 6921.94 & 5269.74 \\
\hline 15 & 285.87 & 173.65 & 229.62 & 104.14 & 269.92 & 208.71 \\
\hline 16 & 53.93 & 39.03 & 50.30 & 33.68 & 52.69 & 40.18 \\
\hline 17 & 777.99 & 587.17 & 686.07 & 473.65 & 768.32 & 603.92 \\
\hline 18 & 189.01 & 143.36 & 166.68 & 122.32 & 186.66 & 150.86 \\
\hline 19 & 7943.04 & 6546.36 & 6764.90 & 5351.75 & 7484.37 & 6044.71 \\
\hline 20 & 298.38 & 234.73 & 274.54 & 213.11 & 287.22 & 233.06 \\
\hline 21 & 396.13 & 282.16 & 369.45 & 250.76 & 387.00 & 296.81 \\
\hline 22 & / & / & / & I & / & / \\
\hline 23 & 53.75 & 41.45 & 47.40 & 34.37 & 53.08 & 42.67 \\
\hline 24 & 299.09 & 213.04 & 278.95 & 189.33 & 292.20 & 224.10 \\
\hline 25 & 72.58 & 57.27 & 66.78 & 53.00 & 69.87 & 57.36 \\
\hline 26 & 0.00 & 0.00 & 0.00 & 0.00 & 0.00 & 0.00 \\
\hline 27 & 63.28 & 30.05 & 44.38 & 12.47 & 59.26 & 41.15 \\
\hline 28 & / & / & / & l & I & l \\
\hline 29 & 95.29 & 61.50 & 76.54 & 37.90 & 89.97 & 67.96 \\
\hline 30 & / & / & / & / & I & / \\
\hline 31 & 215.20 & 164.07 & 189.78 & 132.67 & 212.53 & 168.00 \\
\hline 32 & 82.74 & 74.10 & 52.51 & 42.09 & 69.58 & 59.32 \\
\hline 33 & 671.90 & 512.62 & 592.51 & 403.91 & 663.55 & 518.62 \\
\hline 34 & 369.54 & 281.74 & 325.88 & 227.82 & 364.95 & 288.48 \\
\hline 35 & 0.00 & 0.00 & 0.00 & 0.00 & 0.00 & 0.00 \\
\hline Average & 1253.29 & 980.38 & 1070.61 & 771.24 & 1186.32 & 924.13 \\
\hline Sum & $35,092.13$ & $27,450.72$ & $29,977.20$ & $21,594.67$ & $33,216.84$ & $25,875.68$ \\
\hline
\end{tabular}


Table A12. Yearly absolute $(\mathrm{kg})$ and relative $(\%) \mathrm{CO}_{2}$ emission reduction at farm level if replenishing soil water content to $85 \%$ capacity (FC-WP) instead to FC.

\begin{tabular}{|c|c|c|c|c|c|c|}
\hline \multirow{2}{*}{ Farmer_Id } & \multicolumn{3}{|c|}{$\mathrm{CO}_{2}$ Emission Reduction (kg) } & \multicolumn{3}{|c|}{$\mathrm{CO}_{2}$ Emission Reduction (\%) } \\
\hline & 2017 & 2018 & 2019 & 2017 & 2018 & 2019 \\
\hline 1 & 51.16 & 49.19 & 44.96 & 21.29 & 24.04 & 19.86 \\
\hline 2 & 225.08 & 266.42 & 203.06 & 24.36 & 32.70 & 22.26 \\
\hline 3 & 66.51 & 78.76 & 60.52 & 23.71 & 31.83 & 21.84 \\
\hline 4 & 579.45 & 566.60 & 317.33 & 49.45 & 68.95 & 28.92 \\
\hline 5 & 12.67 & 12.01 & 12.26 & 19.11 & 19.95 & 19.65 \\
\hline 6 & 890.04 & 1098.92 & 1006.46 & 21.90 & 31.75 & 26.28 \\
\hline 7 & 68.97 & 79.90 & 49.05 & 35.70 & 44.57 & 26.02 \\
\hline 8 & 0.00 & 0.00 & 0.00 & I & I & / \\
\hline 9 & 53.21 & 51.15 & 50.01 & 19.39 & 20.84 & 18.82 \\
\hline 10 & 52.59 & 52.62 & 42.00 & 23.06 & 26.16 & 18.64 \\
\hline 11 & 1605.85 & 1684.97 & 1537.81 & 20.22 & 24.91 & 20.55 \\
\hline 12 & 0.00 & 0.00 & 0.00 & I & I & / \\
\hline 13 & 107.24 & 114.15 & 100.24 & 25.01 & 29.77 & 24.15 \\
\hline 14 & 1503.27 & 1794.52 & 1652.19 & 20.29 & 28.14 & 23.87 \\
\hline 15 & 112.22 & 125.48 & 61.21 & 39.25 & 54.65 & 22.68 \\
\hline 16 & 14.90 & 16.62 & 12.51 & 27.62 & 33.03 & 23.74 \\
\hline 17 & 190.81 & 212.42 & 164.40 & 24.53 & 30.96 & 21.40 \\
\hline 18 & 45.65 & 44.36 & 35.80 & 24.15 & 26.61 & 19.18 \\
\hline 19 & 1396.68 & 1413.14 & 1439.66 & 17.58 & 20.89 & 19.24 \\
\hline 20 & 63.64 & 61.43 & 54.16 & 21.33 & 22.38 & 18.86 \\
\hline 21 & 113.97 & 118.70 & 90.19 & 28.77 & 32.13 & 23.31 \\
\hline 22 & I & / & I & I & I & / \\
\hline 23 & 12.30 & 13.03 & 10.42 & 22.88 & 27.48 & 19.62 \\
\hline 24 & 86.05 & 89.62 & 68.10 & 28.77 & 32.13 & 23.31 \\
\hline 25 & 15.31 & 13.78 & 12.51 & 21.09 & 20.63 & 17.90 \\
\hline 26 & 0.00 & 0.00 & 0.00 & I & / & / \\
\hline 27 & 33.23 & 31.91 & 18.11 & 52.52 & 71.90 & 30.56 \\
\hline 28 & I & I & / & I & / & / \\
\hline 29 & 33.79 & 38.64 & 22.01 & 35.46 & 50.49 & 24.47 \\
\hline 30 & I & I & / & I & / & 1 \\
\hline 31 & 51.13 & 57.11 & 44.53 & 23.76 & 30.09 & 20.95 \\
\hline 32 & 8.63 & 10.41 & 10.26 & 10.43 & 19.83 & 14.75 \\
\hline 33 & 159.28 & 188.61 & 144.93 & 23.71 & 31.83 & 21.84 \\
\hline 34 & 87.80 & 98.06 & 76.47 & 23.76 & 30.09 & 20.95 \\
\hline 35 & 0.00 & 0.00 & 0.00 & / & / & I \\
\hline Average & 272.91 & 299.38 & 262.18 & 26.04 & 32.81 & 21.91 \\
\hline Sum & 7641.42 & 8382.52 & 7341.16 & & & \\
\hline
\end{tabular}

\section{References}

1. Yohannes, D.F.; Ritsema, C.J.; Eyasu, Y.; Solomon, H.; van Dam, J.C.; Froebrich, J.; Ritzema, H.P.; Meressa, A. A participatory and practical irrigation scheduling in semiarid areas: The case of Gumselassa irrigation scheme in Northern Ethiopia. Agric. Water Manag. 2019, 218, 102-114. [CrossRef]

2. Cvejić, R.; Černič Istenič, M.; Glavan, M.; Honzak, L.; Klančnik, K.; Kompare, K.; Pintar, M. Increasing climate change resilience in agriculture: Who is responsible? Water Supply 2019, 19, 1405-1412. [CrossRef]

3. Spencer, G.D.; Krutz, L.J.; Falconer, L.L.; Henry, W.B.; Henry, C.G.; Larson, E.J.; Pringle, H.C., III; Bryant, C.J.; Atwill, R.L. Irrigation Water Management Technologies for Furrow-Irrigated Corn that Decrease Water Use and Improve Yield and On-Farm Profitability. Crop. Forage Turfgrass Manag. 2019, 23, 1-8. [CrossRef]

4. Chappell, M.; Dove, S.K.; van Iersel, M.W.; Thomas, P.A.; Ruter, J. Implementation of Wireless Sensor Networks for Irrigation Control in Three Container Nurseries. HortTechnology 2013, 23, 747-753. [CrossRef]

5. Gibson, K.E.B.; Gibson, J.P.; Grassini, P. Benchmarking irrigation water use in producer fields in the US central Great Plains. Environ. Res. Lett. 2019, 14, 054009. [CrossRef] 
6. Gonzalez Perea, R.; Camacho Poyato, E.; Montesinos, P.; Rodriguez Diaz, J.A. Optimization of Irrigation Scheduling Using Soil Water Balance and Genetic Algorithms. Sustain. Water Resour. Manag. 2016, 30, 2815-2830. [CrossRef]

7. Qureshi, A.S. Reducing carbon emissions through improved irrigation management: A case study from Pakistan. Irrig. Drain. 2014, 63, 132-138. [CrossRef]

8. Bryant, C.J.; Krutz, L.J.; Falconer, L.; Irby, J.T.; Henry, C.G.; Pringle, H.C.; Henry, M.E.; Roach, D.P.; Pickelmann, D.M.; Atwill, R.L.; et al. Irrigation Water Management Practices that Reduce Water Requirements for Mid-South Furrow-Irrigated Soybean. Crop. Forage Turfgrass Manag. 2017, 3, 1-7. [CrossRef]

9. Neupane, J.; Guo, W. Agronomic Basis and Strategies for Precision Water Management: A Review. Agronomy 2019, 9, 87. [CrossRef]

10. Kiani, F.; Seyyedabbasi, A. Wireless Sensor Network and Internet of Things in Precision Agriculture. Int. J. Adv. Comput. Sci. Appl. 2018, 9, 99-103. [CrossRef]

11. Villaini, G.; Castaldi, P.; Toscano, A.; Stanghellini, C.; Cinotti, T.S.; Maia, R.F.; Taumberger, M.; Zanetti, P.; Panizzi, S. Soil Water Balance Model CRITERIA-1D in SWAMP Project: Proof of Concept. In Proceedings of the 2018 23rd Conference of Open Innovations Association; Bologna, Italy, 13-16 November 2018; Balandin, S., Ed.; IEEE—Institute of Electrical and Electronics Engineers: Bologna, Italy, 2018; Volume 54, pp. 398-404.

12. Mannini, P.; Genovesi, R.; Letterio, T. IRRINET: Large scale DSS application for on-farm irrigation scheduling. In Four Decades of Progress in Monitoring and Modeling of Processes in the Soil-Plant-Atmosphere System: Applications and Challenges; Romano, N., DUrso, G., Severino, G., Chirico, G.B., Palladino, M., Eds.; Elsevier: Amsterdam, The Netherlands, 2013; Volume 19, pp. 823-829.

13. Brinkhoff, J.; Hornbuckle, J.; Quayle, W.; Lurbe, C.B.; Dowling, T. WiField, an IEEE 802.11-Based Agricultural Sensor Data Gathering and Logging Platform. In Proceedings of the Eleventh International Conference on Sensing Technology; Sydney, Australia, 4-6 December 2017, IEEE-Institute of Electrical and Electronics Engineers: Sydney, Australia, 2017; pp. 226-231.

14. Zapata, N.; Playan, E.; Martinez-Cob, A.; Sanchez, I.; Faci, J.M.; Lecina, S. From on-farm solid-set sprinkler irrigation design to collective irrigation network design in windy areas. Agric. Water Manag. 2007, 24, 187-199. [CrossRef]

15. Baroni, G.; Drastig, K.; Lichtenfeld, A.U.; Jost, L.; Claas, P. Assessment of Irrigation Scheduling Systems in Germany: Survey of the Users and Comparative Study. Irrig. Drain. 2019, 1, 520-530. [CrossRef]

16. Srinivasan, M.S.; Jongmans, C.; Bewsell, D.; Elley, G. Research idea to science for impact: Tracing the significant moments in an innovation based irrigation study. Agric. Water Manag. 2019, 212, 181-192. [CrossRef]

17. Alexander, K.S.; Greenhalgh, G.; Moglia, M.; Thephavanh, M.; Sinavong, P.; Larson, S.; Jovanovic, T.; Case, P. What is technology adoption? Exploring the agricultural research value chain for smallholder farmers in Lao PDR. Agr. Hum. Values 2020, 37, 17-32. [CrossRef]

18. Pagliacci, F.; Defrancesco, E.; Mozzato, D.; Bortolini, L.; Pezzuolo, A.; Pirotti, F.; Pisani, E.; Gatto, P. Drivers of farmers' adoption and continuation of climate-smart agricultural practices. A study from northeastern Italy. Sci. Total. Environ. 2020, 25, 136345. [CrossRef] [PubMed]

19. Dogliotti, S.; García, M.C.; Peluffo, S.; Dieste, J.P.; Pedemonte, A.J.; Bacigalupe, G.F.; Scarlato, M.; Alliaume, F.; Alvarez, J.; Chiappe, M.; et al. Co-innovation of family farm systems: A systems approach to sustainable agriculture. Agric. Syst. 2014, 126, 76-86. [CrossRef]

20. Howley, P.; Donoghue, C.; Heanue, K. Factors Affecting Farmers' Adoption of Agricultural Innovations: A Panel Data Analysis of the Use of Artificial Insemination among Dairy Farmers in Ireland. J. Agric. Sci. 2012, 4, 171-179. [CrossRef]

21. Röling, N. Pathways for impact: Scientists' different perspectives on agricultural innovation. Int. J. Agric. Sustain. 2009, 1, 83-94. [CrossRef]

22. Barnes, A.P.; Soto, I.; Eory, V.; Beck, B.; Balafoutis, A.; Sánchez, B.; Vengeyte, J.; Fountas, S.; van der Wal, T.; Gómez-Barbero, M. Exploring the adoption of precision agricultural technologies: A cross regional study of EU farmers. Land Use Policy 2019, 80, 163-174. [CrossRef]

23. Pierpaoli, E.; Carli, G.; Pignatti, E.; Canavari, M. Drivers of Precision Agriculture Technologies Adoption: A Literature Review. Proc. Technol. 2013, 1, 61-69. [CrossRef] 
24. Jakku, E.; Thorburn, P.J. A conceptual framework for guiding the participatory development of agricultural decision support systems. Agric. Syst. 2010, 1, 675-682. [CrossRef]

25. D'Agostino, D.; Borg, M.; Hallett, S.H.; Sakrabani, R.S.; Thompson, A.; Papadimitriou, L.; Knox, J.W. Multi-stakeholder analysis to improve agricultural water management policy and practice in Malta. Agric. Water Manag. 2020, 229, 105920. [CrossRef]

26. Pigford, E.A.E.; Hickey, G.M.; Klerkx, L. Beyond agricultural innovation systems? Exploring an agricultural innovation ecosystems approach for niche design and development in sustainability transitions. Agric. Syst. 2018, 1, 116-121. [CrossRef]

27. Touzard, J.M.; Temple, L.; Faure, G.; Triomphe, B. Innovation systems and knowledge communities in the agriculture and agrifood sector: A literature review. J. Innov. Econ. Manag. 2015, 17, 117-142. [CrossRef]

28. World Bank. Enhancing Agricultural Innovation: How to go Beyond the Strengthening of Research Systems; World Bank: Washington, DC, USA, 2007; pp. 1-188.

29. Faure, G.; Knierim, A.; Koutsouris, A.; Ndah, H.T.; Audouin, S.; Zarokosta, E.; Wielinga, E.; Triomphe, B.; Mathe, S.; Temple, L.; et al. How to Strengthen Innovation Support Services in Agriculture with Regard to Multi-Stakeholder Approaches. J. Innov. Econ. Manag. 2019, 28, 145-169. [CrossRef]

30. Knierim, A.; Kernecker, M.; Erdle, K.; Kraus, T.; Borges, F.; Wurbs, A. Smart farming technology innovations-Insights and reflections from the German Smart-AKIS hub. NJAS Wagen. J. Life Sci. 2019, 1, 100314. [CrossRef]

31. Koutsouris, A. Role of Extension in Agricultural Technology Transfer: A Critical Review. In From Agriscience to Agribusiness: Theories, Policies and Practices in Technology Transfer and Commercialization; Kalaitzandonakes, N., Carayannis, E.G., Grigoroudis, E., Rozakis, S., Eds.; Springer International Publishing: Cham, Switzerland, 2018; pp. 337-359.

32. Lioutas, E.D.; Charatsari, C.; Istenič, M.Č.; Rocca, G.L.; Rosa, M.D. The challenges of setting up the evaluation of extension systems by using a systems approach: The case of Greece, Italy and Slovenia. J. Agric. Educ. Ext. 2019, 25, 139-160. [CrossRef]

33. Garcia Morillo, J.; Martin, M.; Camacho, E.; Rodriguez Diaz, J.A.; Montesinos, P. Toward precision irrigation for intensive strawberry cultivation. Agric. Water Manag. 2015, 1, 43-51. [CrossRef]

34. Jacob, D.; Petersen, J.; Eggert, B.; Alias, A.; Christensen, O.B.; Bouwer, L.M.; Braun, A.; Colette, A.; Déqué, M.; Georgievski, G.; et al. EURO-CORDEX: New high-resolution climate change projections for European impact research. Reg. Environ. Chang. 2014, 1, 563-578. [CrossRef]

35. Honzak, L.; Glavan, M.; Pintar, M. Analysis of Climate Change Projections. Deliverable A1b. Project Adapting to the impacts of Climate Change in the Vipava Valley_LIFE ViVaCCAdapt (LIFE15 CCA/SI/000070); University of Ljubljana: Ljubljana, Slovenia, 2017; pp. 1-13.

36. Bertalanič, R.; Dolinar, M.; Honzak, L.; Lovše, N.; Medved, A.; Vertačnik, G.; Živa, V. Climate Change Projections for Slovenia Over the 21st Century; Ministry of the Environment and Spatial Planning, Slovenian Environment Agency: Ljubljana, Slovenia, 2019; pp. 1-13.

37. ARSO. Meteo.si Uradna Vremenska Napoved za Slovenijo. Available online: https://meteo.arso.gov.si/ (accessed on 20 April 2020).

38. Sušnik, A.; Matajc, I.; Kodrič, I. Agrometeorological support of fruit production: Application in SW Slovenia. Meteorol. Appl. 2007, 26, 81-86. [CrossRef]

39. Sušnik, A. Scheme of Indicators for Drought Monitoring on Agricultural Land. Ph.D. Thesis, University of Ljubljana, Ljubljana, Slovenia, 2014.

40. Vaz, C.M.P.; Jones, S.; Meding, M.; Tuller, M. Evaluation of Standard Calibration Functions for Eight Electromagnetic Soil Moisture Sensors. Vadose Zone J. 2013, 1, 1-6. [CrossRef]

41. Weitz, A.M.; Grauel, W.T.; Keller, M.; Veldkamp, E. Calibration of time domain reflectometry technique using undisturbed soil samples from humid tropical soils of volcanic origin. Water Resour. Res. 1997, 1, 1241-1249. [CrossRef]

42. Provenzano, G.; Rallo, G.; Ghazouani, H. Assessing Field and Laboratory Calibration Protocols for the Diviner 2000 Probe in a Range of Soils with Different Textures. J. Irrig. Drain. Eng. ASCE 2015, 142. [CrossRef]

43. Holzman, M.; Rivas, R.; Carmona, F.; Niclòs, R. A method for soil moisture probes calibration and validation of satellite estimates. MethodsX 2017, 1, 243-249. [CrossRef]

44. Pintar, M. Irrigation Guidelines with Emphasis on Vegetables and Fruit Species in Western, Central and Southern Slovenia; Ministry of Agriculture, Forestry and Food: Ljubljana, Slovenia, 2006; pp. 1-56. 
45. Allen, R.; Pereira, L.; Raes, D.; Smith, M. Crop Evapotranspiration-Guidelines for Computing Crop Water Requirements. In FAO Irrigation and Drainage Paper 56; FAO_-Food and Agriculture Organization of the United Nations: Rome, Italy, 1998.

46. Battilani, A.; Letterio, T. Irrigation Strategy Selection Criteria, Tools and Algorithms for Precise Irrigation Application. Task 5.1 Irrigation Strategies Selection Deliverable 5.1. Project FIGARO_Flexible and PrecIse IrriGation PlAtform to Improve FaRm Scale Water PrOductivity; Netafim: Tel Aviv-Yafo, Israel, 2014; pp. 1-24.

47. Official Gazette of the Republic of Slovenia. Rules on the Methods for Determining Energy Savings No. 67/15. Available online: http://www.pisrs.si/Pis.web/pregledPredpisa?id=PRAV12443 (accessed on 20 April 2020).

48. Official Gazette of the Republic of Slovenia. Rules on the Methods for Determining Energy Savings No. 14/17. Available online: http://www.pisrs.si/Pis.web/pregledPredpisa?id=PRAV12443 (accessed on 20 April 2020).

49. Robinson, D.; Campbell, C.; Hopmans, J.; Hornbuckle, B.K.; Jones, S.; Knight, R.; Ogden, F.; Selker, J.; Wendroth, O. Soil Moisture Measurement for Ecological and Hydrological Watershed-Scale Observatories: A Review. Vadose Zone J. 2008, 1, 358-389. [CrossRef]

50. Zotarelli, L.; Dukes, M.; Scholberg, J.; Femminella, K.; Muñoz-Carpena, R. Irrigation Scheduling for Green Bell Peppers Using Capacitance Soil Moisture Sensors. J. Irrig. Drain. Eng. ASCE 2011, 137, 73-81. [CrossRef]

51. Millán, S.; Casadesús, J.; Campillo Torres, C.; Moñino, M.; Prieto, M. Using Soil Moisture Sensors for Automated Irrigation Scheduling in a Plum Crop. Water 2019, 11, 2061. [CrossRef]

52. Evett, S.R.; Parkin, G.W. Advances in Soil Water Content Sensing: The Continuing Maturation of Technology and Theory. Vadose Zone J. 2005, 4, 986-991. [CrossRef]

53. Bogena, H.R.; Huisman, J.A.; Oberdörster, C.; Vereecken, H. Evaluation of a low-cost soil water content sensor for wireless network applications. J. Hydrol. 2007, 344, 32-42. [CrossRef]

54. Nemali, K.S.; Montesano, F.; Dove, S.K.; van Iersel, M.W. Calibration and performance of moisture sensors in soilless substrates: ECH2O and Theta probes. Sci. Hortic. 2007, 112, 227-234. [CrossRef]

55. Roth, G.; Harris, G.; Gillies, M.; Montgomery, J.; Wigginton, D. Water-use efficiency and productivity trends in Australian irrigated cotton: A review. Crop Pasture Sci. 2013, 64, 1033-1048. [CrossRef]

56. Greenhalgh, G.; Moglia, M.; Alexander, K.; Jovanovic, T.; Sacklokham, S.; Khounsy, B.; Thaphavanh, M.; Inthavong, T.; Vorlasan, S.; Khampasrt. Smallholder Farmer Decision-Making and Technology Adoption in Southern Lao PDR: Opportunities and Constraints. Activity 1.1: Farmer Perception Survey; Project Number ASEM/2014/052; Australian Centre for International Agricultural Research (ACIAR): Canbera, Australia, 2017; pp. 1-86.

57. Morgan, M.I.; Hine, D.W.; Bhullar, N.; Loi, N.M. Landholder adoption of low emission agricultural practices: A profiling approach. J. Environ. Psychol. 2015, 41, 35-44. [CrossRef] 